\title{
Kompetencja Rzecznika Finansowego do nakładania kar pieniężnych na podmioty rynku finansowego
}

\section{Wprowadzenie}

Przedmiotem rozważań są kompetencje Rzecznika Finansowego (dalej "Rzecznik" lub „Rzecznik Finansowy") do nakładania na podmioty rynku finansowego kar pieniężnych w związku z naruszeniami przepisów Ustawy z dnia 5 sierpnia 2015 r. o rozpatrywaniu reklamacji przez podmioty rynku finansowego i o Rzeczniku Finansowym ${ }^{1}$. Ustawa ta nakłada na podmioty rynku finansowego (art. 2 pkt 3 ustawy o Rzeczniku) ściśle określone obowiązki dotyczące postępowania reklamacyjnego ${ }^{2}$, z którymi skorelowane są odpowiednie uprawnienia klientów (art. 2 pkt 1 ustawy o Rzeczniku) tych podmiotów. Po pierwsze, w przypadku zastrzeżeń do usług świadczonych przez podmioty rynku finansowego klientom przysługuje prawo do wniesienia reklamacji ${ }^{3}$. Wiąże się z tym obowiązek podmiotu rynku finansowego do jej rozpatrzenia i udzielania odpowiedzi w przewidzianych ustawą o Rzeczniku terminach (art. 6-8 ustawy o Rzeczniku), formie (art. 5 ustawy o Rzeczniku) i zakresie (art. 9-10 ustawy o Rzeczniku). Ponadto na podmiotach rynku

${ }^{1}$ Tekst jedn. Dz.U. 2017, poz. 2270, dalej „ustawa o Rzeczniku”. Ustawa ta weszła w życie z dniem 11 października 2015 r. (art. 64 ustawy o Rzeczniku).

${ }^{2}$ Rozdział 2 zatytułowany "Rozpatrywanie reklamacji przez podmioty rynku finansowego" (art. 3-10) ustawy o Rzeczniku.

${ }^{3}$ Zgodnie z art. 2 pkt 2 ustawy o Rzeczniku reklamacja to wystapienie skierowane do podmiotu rynku finansowego przez jego klienta, w którym klient zgłasza zastrzeżenia dotyczące usług świadczonych przez podmiot rynku finansowego. Sposoby i formy składania reklamacji reguluje art. 3 ustawy o Rzeczniku. 
finansowego ciąży obowiązek umieszczania w zawieranych z klientami umowach informacji o możliwości wniesienia reklamacji (art. 4 ust. 1 ustawy o Rzeczniku). W odniesieniu do klientów, którzy nie zawarli umowy z podmiotem rynku finansowego, informacje te powinny zostać dostarczone w ciągu 7 dni od dnia, w którym nastąpiło zgłoszenie roszczeń klienta wobec podmiotu rynku finansowego (art. 4 ust. 2 ustawy o Rzeczniku). Podmioty rynku finansowego obowiązane są zatem posiadać odpowiednie procedury, zapewniające - zgodne z przepisami ustawy o Rzeczniku - rozpatrywanie reklamacji klientów.

Zarazem ustawa o Rzeczniku powołała instytucję Rzecznika Finansowego, której celem jest działanie na rzecz ochrony klientów podmiotów rynku finansowego ${ }^{4}$. Głównym zadaniem Rzecznika jest rozpatrywanie wniosków klientów w indywidualnych sprawach, wniesionych na skutek nieuwzględnienia roszczeń klienta przez podmiot rynku finansowego w trybie rozpatrywania reklamacji (art. 17 ust. 1 pkt 1 i 2, art. 24 i 25 ustawy o Rzeczniku), pozasądowe rozwiązywanie sporów ${ }^{5}$, a także rozpatrywanie wniosków o wydanie istotnego poglądu w sprawie (art. 28 ustawy o Rzeczniku) ${ }^{6}$, gdy spór znajduje się już na etapie sądowym. Warto dodać, że od 3 kwietnia 2018 r. ${ }^{7}$ Rzecznik Finansowy ma również kompetencję do wnoszenia skargi nadzwyczajnej (art. $89 \S 2$ ustawy o SN). W związku z powyższym Rzecznikowi przysługują odpowiednie uprawnienia względem podmiotów rynku finansowego (art. 25, art. 27 pkt 2, art. 30 oraz art. 31 ustawy o Rzeczniku). W szczególności Rzecznik lub upoważniony przez niego pracownik Biura Rzecznika może występować do podmiotów rynku finansowego oraz innych podmiotów, których działalność wiąże się z rozpatrywaną sprawą, o udzielenie

${ }^{4}$ Uzasadnienie do poselskiego projektu ustawy o rozpatrywaniu reklamacji przez podmioty rynku finansowego i o Rzeczniku Finansowym (druk sejmowy nr 3430/VII kadencja), s. 12, http://www.sejm.gov.pl/sejm7.nsf/druk.xsp?nr=3430 (dostęp: 5 V 2018).

${ }^{5}$ Rozdział 4 zatytułowany „Pozasądowe postępowanie w sprawie rozwiązywania sporów między klientem a podmiotem rynku finansowego" (art. 35-43) ustawy o Rzeczniku.

${ }^{6} \mathrm{Na}$ temat kompetencji Rzecznika Finansowego do wydawania istotnego poglądu w sprawie zob. B. Wyżykowski, Istotny pogląd Rzecznika Finansowego jako instrument ochrony klientów podmiotów rynku finansowego, "Studia Prawa Publicznego” 2018, nr 1(21), s. 121. Warto dodać, że na podstawie art. 26 ustawy o Rzeczniku Rzecznik Finansowy może również wytoczyć powództwo na rzecz klientów podmiotów rynku finansowego w sprawach dotyczących nieuczciwych praktyk rynkowych dotyczących działalności tych podmiotów, jak również za zgodą powoda wziąć udział w toczącym się już postępowaniu. W takim przypadku stosuje się odpowiednio przepisy o prokuratorze.

${ }^{7}$ Ustawa z dnia 8 XII 2017 r. o Sądzie Najwyższym (Dz.U. 2018, poz. 5 ze zm.), dalej "ustawa o SN", art. 136. 
informacji lub wyjaśnień, udostępnienie akt oraz dokumentów (art. 25 ust. 1 pkt 1 ustawy o Rzeczniku). Wiąże się z tym obowiązek podmiotów rynku finansowego poinformowania Rzecznika o podjętych działaniach lub zajętym stanowisku oraz obowiązek przekazania żądanych dokumentów (art. 31 ustawy o Rzeczniku). Konsekwentnie, jednym z głównych zadań Rzecznika jest egzekwowanie należytego wykonywania przez podmioty rynku finansowego omawianych obowiązków wynikających z ustawy o Rzeczniku. W tym celu art. 32 ust. 1 tego aktu przewiduje, że w przypadku naruszenia wskazanych w nim przepisów ustawy o Rzeczniku Rzecznik Finansowy może, w drodze decyzji, nałożyć karę pieniężną do wysokości 100000 zł.

Krótki czas obowiązywania nowych przepisów i w konsekwencji brak orzecznictwa nakreślającego kierunki ich wykładni w początkowym okresie z pewnością może powodować wątpliwości w zakresie ich stosowania. Celem artykułu jest zasygnalizowanie możliwych zagadnień spornych i przedstawienie propozycji ich rozstrzygnięcia. W szczególności omówienia wymagają przesłanki nałożenia na podmiot rynku finansowego kary pieniężnej, przy czym chodzi tu nie tylko o analizę konkretnych deliktów wskazanych w art. 32 ust. 1 ustawy o Rzeczniku, ale także o przedstawienie ogólnych zasad związanych z nakładaniem administracyjnych kar pieniężnych, w szczególności w ramach tzw. uznania administracyjnego. Rozpatrzenia wymagają również zasady ustalania wysokości kary pieniężnej i wzajemna relacja art. 32 (ust. 2) ustawy o Rzeczniku ${ }^{8}$ oraz przepisów Działu IVa Kodeksu postępowania administracyjnego ${ }^{9}$ regulujących sprawy nakładania i wymierzania administracyjnych kar pieniężnych i udzielania ulg w ich wykonaniu ${ }^{10}$. Wskazane zostaną też uwagi o charakterze de lege ferenda, zawierające propozycje zmian przepisów ustawy o Rzeczniku, mające na celu zwiększenie skuteczności podejmowanych przez Rzecznika Finansowego działań, a w konsekwencji także poziomu ochrony klientów podmiotów rynku finansowego. Warto zaznaczyć, że opracowanie, w części dotyczącej charakteru kary pieniężnej jako rodzaju sankcji administracyjnej i przesłanek jej nakładania, opiera się na analizie orzecznictwa sądów

${ }^{8}$ Zgodnie z art. 32 ust. 2 ustawy o Rzeczniku „Przy ustalaniu wysokości kary pieniężnej, o której mowa w ust. 1, uwzględnia się stopień naruszenia przepisów, okoliczności tego naruszenia oraz możliwości finansowe podmiotu, który dokonał naruszenia".

${ }^{9}$ Ustawa z dnia 14 VI 1960 r. Kodeks postępowania administracyjnego (tekst jedn.

Dz.U. 2017, poz. 1257), dalej „k.p.a.”.

${ }^{10}$ Dział IVa (art. 189a-189k) k.p.a. 
administracyjnych, ukształtowanego na tle kar pieniężnych nakładanych przez inne organy. Uwagi zawarte w paragrafach 2 i 6 mają więc charakter systemowy, odnoszący się do administracyjnych kar pieniężnych (i postępowania administracyjnego prowadzonego w tym zakresie) w ogólności.

\section{Decyzja o nałożeniu kary pieniężnej}

Na wstępie ustalenia wymaga charakter prawny decyzji Rzecznika Finansowego o nałożeniu kary pieniężnej oraz to, jakie konsekwencje (uprawnienia i obowiązki) wiążą się z tym zarówno dla Rzecznika Finansowego, jak i dla podmiotów rynku finansowego. Warto zaznaczyć, że co do zasady działania lub czynności Rzecznika Finansowego nie kształtują władczo praw ani obowiązków podmiotów rynku finansowego, w tym zwłaszcza relacji prawnych między tymi podmiotami a ich klientami ${ }^{11}$. Działania podejmowane na podstawie art. 17, art. 24-30 oraz art. 35-43 ustawy o Rzeczniku nie są więc objęte dyspozycją norm zawartych w art. 1 i 2 k.p.a., a tym samym nie są one regulowane przepisami k.p.a. ${ }^{12} \mathrm{~W}$ tym zakresie ustawa o Rzeczniku nie przewiduje zatem uprawnienia Rzecznika Finansowego do wydawania aktów administracyjnych wskazanych w art. 3 \& 2 pkt 1-7 Prawa o postępowaniu przed sądami administracyjnymi ${ }^{13}$. Konsekwentnie, działania te nie są również objęte dyspozycją normy zawartej w art. 3 § 1 i 2 pkt 8 i 9 p.p.s.a. ${ }^{14}$

${ }^{11}$ Zob. B. Wyżykowski, Istotny pogląd Rzecznika Finansowego..., s. 137, 138.

12 Ibidem.

${ }^{13}$ Ustawa z dnia 30 VIII 2002 r. Prawo o postępowaniu przed sądami administracyjnymi (tekst jedn. Dz.U. 2018, poz. 1302), dalej „p.p.s.a.”.

${ }^{14}$ W szczególności czynności podejmowane przez Rzecznika Finansowego nie spełniają dyspozycji art. $3 \S 2$ pkt 4 p.p.s.a. Przepis ten umożliwia zaskarżalność innej grupy aktów administracyjnych (takich, które nie są decyzjami administracyjnymi lub postanowieniami), które dotyczą uprawnień lub obowiązków wynikających z przepisów prawa. W doktrynie wskazuje się, że „[z]akres przedmiotowy aktów dotyczących uprawnień lub obowiązków wynikających z przepisów prawa należy ograniczyć do przepisów materialnego prawa administracyjnego, które wyłączają możliwość wydania decyzji czy postanowienia, wymagają jednak od organu wykonującego administrację publiczną potwierdzenia obowiązku lub uprawnienia. [...] Podstawowe znaczenie dla przeprowadzenia przedmiotowej delimitacji pomiędzy aktami dającymi się przyporządkować kognicji sądów administracyjnych na podstawie art. $3 \S 2$ pkt 4 p.p.s.a. ma więc to, czy norma prawa administracyjnego wymaga konkretyzacji przy wykorzystaniu sformalizowanej procedury administracyjnej (na przykład k.p.a.). [...] Należy bez wątpienia wyłączyć przepisy prawa, które kształtują uprawnienia lub obowiązki bezpośrednio 
Stanowisko takie znajduje też odzwierciedlenie w orzecznictwie sądów administracyjnych ${ }^{15}$.

Przepisy prawa przewidują jednak pewne wyjątki w tej materii. Jednym z nich jest sytuacja, w której Rzecznik Finansowy wydaje decyzję o odmowie ujawnienia informacji publicznej na podstawie przepisów ustawy o dostępie do informacji publicznej ${ }^{16}$. Należy przyjąć, że kolejny wyjątek przewidziany jest wprost w ustawie o Rzeczniku, właśnie w jej art. 32. Jakkolwiek w przepisie tym nie wskazano explicite, że decyzja o nałożeniu kary pieniężnej ma charakter decyzji administracyjnej, ani też że wydawana jest na podstawie przepisów k.p.a., brak jest podstaw, by przyjąć odmienne stanowisko w tym zakresie ${ }^{17}$. Należy pamiętać, że

z mocy prawa. [...] Dyspozycją normy zawartej w art. $3 \S 2$ pkt 4 p.p.s.a. objęte są zatem tylko takie akty lub czynności organów administracji publicznej, których przedmiotem jest przyznanie (odmowa przyznania), stwierdzenie (odmowa stwierdzenia) albo uznanie (odmowa uznania) określonego uprawnienia lub obowiązku wynikających z mocy powszechnie obowiązującego przepisu prawa" (J. Drachal, J. Jagielski, R. Stankiewicz, Komentarz do art. 3, w: Prawo o postępowaniu przed sądami administracyjnymi. Komentarz, pod red. R. Hausera, M. Wierzbowskiego, Warszawa 2017).

${ }^{15}$ Zob. postanowienie Naczelnego Sądu Administracyjnego (NSA) w Warszawie z 29 XI 2016 r., sygn. I OZ 1484/16, Legalis nr 1550520, w którym wskazano, że "[w] rozpoznawanej sprawie skarżący zarzucił Rzecznikowi Ubezpieczonych bezczynność polegającą na niedoręczeniu polisy OC. Sąd I instancji prawidłowo stwierdził, że przedmiotowa skarga na bezczynność nie należy do właściwości sądu administracyjnego, albowiem nie dotyczy żadnego z aktów administracyjnych wymienionych w art. 3 \& 2 pkt 1-4 p.p.s.a. W tej sytuacji prawo pomocy nie przysługuje i Sąd zasadnie odmówił skarżącemu przyznania prawa pomocy na podstawie art. 247 p.p.s.a."; wyrok NSA w Warszawie z 6 VII 2004 r., sygn. OSK 547/04, Legalis nr 66298, w którym stwierdzono, że „[w] sytuacji gdy skarga na bezczynność została wniesiona w sprawie, do której załatwienia nie jest właściwy wskazany przez stronę organ, a która ponadto nie podlega załatwieniu w drodze administracyjnej, lecz w drodze umowy, właściwe jest orzeczenie przez sąd administracyjny o odrzuceniu skargi jako niedopuszczalnej (art. 27 ust. 2 Ustawy z dnia 11 V 1995 r. o Naczelnym Sądzie Administracyjnym - Dz.U. Nr 74, poz. 368 ze zm., obecnie art. 58 \& 1 pkt 1 Ustawy z dnia 30 VIII 2002 r. - Prawo o postępowaniu przed sądami administracyjnymi - Dz.U. Nr 153, poz. 1270)".

${ }^{16}$ Ustawa z dnia 6 IX 2001 r. o dostępie do informacji publicznej (tekst jedn. Dz.U. 2018, poz. 1330), dalej „u.o.d.i.p.”. Zgodnie z art. 16 ust. 1 tej ustawy odmowa udostępnienia informacji publicznej oraz umorzenie postępowania o udostępnienie informacji przez organ władzy publicznej następują w drodze decyzji.

${ }^{17} \mathrm{~W}$ doktrynie $\mathrm{w}$ przeważającej mierze przyjmuje się domniemanie działania administracji publicznej $\mathrm{w}$ formie decyzji administracyjnej, kiedy rozstrzyga się o sytuacji prawnej danego podmiotu. W związku $\mathrm{z}$ tym o charakterze prawnym podejmowanych czynności nie decyduje nazwa, lecz treść, kryterium kwalifikującym akt organu do kategorii decyzji administracyjnej jest zaś władcze i jednostronne rozstrzygnięcie o prawach i obowiązkach indywidualnych adresatów, niepodporządkowanych podmiotowi wydającemu takie rozstrzygnięcie (J. Drachal, J. Jagielski, R. Stankiewicz, Komentarz do art. 3). 
nałożenie kary pieniężnej stanowi ingerencję w sferę interesów podmiotu rynku finansowego. I choć maksymalny limit kary w postaci $100000 \mathrm{zł}$ za naruszanie (naruszenia) poszczególnych przepisów wskazanych w art. 32 ust. 1 ustawy o Rzeczniku na tle kar przewidzianych w innych ustawach ${ }^{18}$ może się wydawać niewielki, podmioty rynku finansowego muszą mieć zapewnione odpowiednie gwarancje procesowe w celu obrony swoich praw. Źródła tych gwarancji wynikają z Konstytucji Rzeczypospolitej Polskiej ${ }^{19}$, a także z prawa unijnego. Artykuł 45 ust. 1 Konstytucji RP gwarantuje każdemu prawo do rozpatrzenia sprawy przez niezależny i niezawisły sąd. Z orzecznictwa Trybunału Konstytucyjnego (TK) wynika zaś, że prawo do sądu jest zachowane na gruncie takich regulacji, które zapewniają kontrolę sądową rozstrzygnięcia, decyzji czy innego aktu indywidualnego kształtującego sytuację prawną podmiotu poprzez uruchomienie postępowania przed sądem powszechnym lub sądem administracyjnym ${ }^{20}$. Podstawę konstytucyjną funkcjonowania sądownictwa administracyjnego stanowi natomiast art. 184 Konstytucji $\mathrm{RP}$, który ustanawia standard sądowej kontroli działań administracji publicznej ${ }^{21}$. Przyjmuje się, że zgodnie z art. 175 ust. 1 Konstytucji RP

${ }^{18}$ Przykładowo, zob. art. 106 i n. Ustawy z dnia 16 II 2007 r. o ochronie konkurencji i konsumentów (tekst jedn. Dz.U. 2018, poz. 798), dalej „ustawa u.o.k.i.k.”. Na podstawie art. 106 ust. 1 tego aktu Prezes Urzędu może nałożyć na przedsiębiorcę, w drodze decyzji, karę pieniężną w wysokości nie większej niż 10\% obrotu osiągniętego w roku obrotowym poprzedzającym rok nałożenia kary. Z kolei na podstawie art. 106 ust. 2 ustawy u.o.k.i.k. Prezes UOKiK może nałożyć na przedsiębiorcę, w drodze decyzji, karę pieniężną w wysokości stanowiącej równowartość do 50000000 euro. Warto przy tym wskazać, że w istocie zarówno art. 106 ust. 2 pkt 2 ustawy u.o.k.i.k., jak i art. 32 w zw. z art. 31 ustawy o Rzeczniku inkryminują takie samo zachowanie, polegające na nieprzekazaniu organowi żądanych informacji lub przekazaniu informacji nieprawdziwych lub wprowadzających w błąd. Podobnie górna granica kar pieniężnych, do których nakładania uprawniona jest Komisja Nadzoru Finansowego (dalej „KNF”), niejednokrotnie przewyższa kwotę 100000 zł (np. art. 138 ust. 3 pkt 3a Ustawy z dnia 29 VIII 1997 r. - Prawo bankowe (tekst jedn. Dz.U. 2017, poz. 1876), dalej „ustawa - Prawo bankowe", art. 362 ust. 1 pkt 2 Ustawy z dnia 11 IX 2015 r. o działalności ubezpieczeniowej i reasekuracyjnej (tekst jedn. Dz.U. 2018, poz. 999), dalej „ustawa o działalności ubezpieczeniowej i reasekuracyjnej").

${ }^{19}$ Konstytucja Rzeczypospolitej Polskiej z dnia 2 IV 1997 r. (Dz.U. Nr 78, poz. 483 ze zm.), dalej „Konstytucja RP.”

${ }^{20}$ Wyrok Trybunału Konstytucyjnego (TK) z 2 VI 1999 r., sygn. K 34/98, OTK 1999, nr 5, poz. 94; wyrok TK z 4 III 2008 r., sygn. SK 3/07, OTK-A 2008, nr 2, poz. 25; wyrok TK z 13 III 2012 r., sygn. P 39/10, OTK-A 2012, nr 3, poz. 26.

${ }^{21}$ J.P. Tarno, Rozdział V § 26 pkt VI, w: Sadowa kontrola administracji publicznej, seria System Prawa Administracyjnego, pod red. R. Hausera, Z. Niewiadomskiego, A. Wróbla, t. 10, Warszawa 2016. 
sądy administracyjne sprawują wymiar sprawiedliwości, a więc realizują prawo jednostki do sądu (art. 45 Konstytucji RP) ${ }^{22}$. Z omawianych przepisów wynika więc, że sądy administracyjne realizują prawo do sądu, wymierzając sprawiedliwość przez kontrolę działalności administracji publicznej, co znajduje również odzwierciedlenie w art. 3 § 1 p.p.s.a. W doktrynie wskazuje się, że istotą prawa do sądu w sprawach wynikających z działań administracji publicznej jest przyznana adresatowi aktu czy czynności z zakresu administracji publicznej możliwość zainicjowania przed sądem administracyjnym postępowania służącego skontrolowaniu działalności administracji z punktu widzenia zgodności z prawem ${ }^{23}$. Prawo do skutecznego środka prawnego i dostępu do bezstronnego sądu wynika również z art. 47 Karty praw podstawowych $\mathrm{UE}^{24}$. Prawo przedsiębiorców (w tym podmiotów rynku finansowego) do obrony potwierdzone zostało w orzecznictwie TSUE ${ }^{25}$. Opierając się na zasadzie skutecznej ochrony sądowej, przedsiębiorca, na którego nałożona zostanie kara pieniężna, musi więc dysponować możliwością wniesienia środka prawnego przeciwko nałożeniu tej kary ${ }^{26}$. Ponadto środki podejmowane wobec przedsiębiorców, w tym kary pieniężne, muszą pozostawać $\mathrm{w}$ zgodzie $\mathrm{z}$ zasadą proporcjonalności ${ }^{27}$, w związku z czym przedsiębiorcy muszą mieć również możliwość zakwestionowania wysokości kary ${ }^{28}$.

Nie powinno zatem budzić wątpliwości, że na podstawie art. 32 ustawy o Rzeczniku kara pieniężna nakładana jest przez Rzecznika Finansowego w formie decyzji administracyjnej, stanowiąc rodzaj sankcji

${ }^{22}$ M. Wiącek, Komentarz do art. 184, w: Konstytucja RP, t. 2: Komentarz do art. 87-243, pod red. M. Safjana, L. Boska, Warszawa 2016.

${ }^{23}$ Ibidem.

${ }^{24}$ Karta praw podstawowych Unii Europejskiej (OJ C 326, 26 X 2012 r., s. 391-407), dalej „Karta praw podstawowych UE”. W przedmiocie prawa przedsiębiorcy do bycia wysłuchanym wynikającego z Karty praw podstawowych UE zob. wyrok Trybunału Sprawiedliwości Unii Europejskiej (TSUE) z 21 XII 2016 r. w sprawie C-119/15, Biuro podróży "Partner" sp.z o.o.sp.k. w Dąbrowie Górniczej przeciwko Prezesowi Urzędu Ochrony Konkurencji i Konsumentów (ECLI:EU:C:2016:987), dalej „wyrok TSUE z 21 XII 2016 r. w sprawie C-119/15", pkt 40-47. Zob. też opinię Rzecznika Generalnego Henrika Saugmandsgaarda ØE przedstawioną w dniu 2 VI 2016 r., Sprawa C-119/15 Biuro podróży "Partner" Sp. z o.o., Sp. komandytowa w Dąbrowie Górniczej przeciwko Prezesowi Urzędu Ochrony Konkurencji i Konsumentów (ECLI:EU:C:2016:387), pkt 58-71.

${ }^{25}$ Wyrok TSUE z 21 XII 2016 r. w sprawie C-119/15, pkt 43.

${ }^{26}$ Ibidem, pkt 40, 43.

${ }^{27}$ Ibidem, pkt 45, 46.

${ }^{28}$ Ibidem, pkt 45 . 
administracyjnej ${ }^{29}$. Postępowanie w przedmiocie jej nałożenia jest natomiast postępowaniem, o którym mowa w art. 1 k.p.a. ${ }^{30}$, a decyzja o jej nałożeniu stanowi - podlegający kontroli sądów administracyjnych - akt, o którym mowa w art. $3 \& 2$ pkt 1 p.p.s.a. Za takim stanowiskiem przemawia również fakt, że z dniem 1 czerwca 2017 r. do k.p.a. wprowadzono Dział IVa zatytułowany „Administracyjne kary pieniężne ${ }^{\prime 31}$, regulujący sprawy nakładania i wymierzania ${ }^{32}$ administracyjnych kar pieniężnych oraz udzielania ulg w ich wykonaniu. Zgodnie $z$ art. 189b k.p.a. przez administracyjną karę pieniężną rozumie się określoną w ustawie sankcję o charakterze pieniężnym, nakładaną przez organ administracji publicznej, w drodze decyzji, w następstwie naruszenia prawa polegającego na niedopełnieniu obowiązku albo naruszeniu zakazu ciążącego na osobie fizycznej, osobie prawnej lub jednostce organizacyjnej nieposiadającej osobowości prawnej. Kara pieniężna, o której mowa w art. 32 ustawy o Rzeczniku, spełnia wszystkie przesłanki wskazane w art. 189b k.p.a. Niewątpliwie, jest to sankcja o charakterze pieniężnym, mająca swoją podstawę w przepisach ustawy o Rzeczniku, nakładana w formie decyzji przez organ, jakim jest Rzecznik Finansowy, w następstwie niedopełnienia lub nienależytego wypełnienia obowiązków wynikających z przepisów ustawy o Rzeczniku wskazanych w art. 32 ust. 1 tego aktu. Poszczególnych przepisów Działu IVa nie stosuje się natomiast wówczas, gdy odpowiednie zagadnienia dotyczące kar pieniężnych uregulowane zostały przepisami szczególnymi ${ }^{33}$. Relacja art. 32 (ust. 2)

${ }^{29}$ Sankcją administracyjną może być bowiem również inne zachowanie organu o charakterze niepieniężnym, stanowiące dla jednostki pewnego rodzaju dolegliwość, np. cofnięcie zezwolenia na prowadzenie określonej działalności gospodarczej, wygaszenie uprawnień, zakaz ubiegania się o zezwolenie lub koncesję przez określony czas, nakaz publikacji określonego oświadczenia w mediach.

${ }^{30}$ Wątpliwości może natomiast budzić to, czy postępowanie Rzecznika Finansowego prowadzone na podstawie art. 32 ustawy o Rzeczniku jest postępowaniem, o którym mowa w art. 1 pkt 1 czy też art. 1 pkt 2 k.p.a. Niemniej nie budzi wątpliwości, że organ, jakim jest Rzecznik Finansowy, powołany jest z mocy prawa (art. 32 ustawy o Rzeczniku) do załatwienia indywidualnych spraw podmiotów rynku finansowego rozstrzyganych $\mathrm{w}$ drodze decyzji administracyjnych w przedmiocie nałożenia na nie kar pieniężnych za naruszenia przepisów ustawy o Rzeczniku wskazanych w art. 32 ust. 1 tego aktu.

${ }^{31}$ Artykuły 189a-189k k.p.a.

${ }^{32} \mathrm{~W}$ doktrynie wskazuje się, że rozróżnienie pojęć "nakładania” $i$ „wymierzania” nie ma istotnego znaczenia normatywnego i należy uznać je raczej za konsekwencję zamiennego ich używania przez prawodawcę w licznych aktach normatywnych dotyczących administracyjnych kar pieniężnych (M. Jabłoński, Komentarz do art. 189a, w: Kodeks postępowania administracyjnego. Komentarz, pod red. M. Wierzbowskiego, A. Wiktorowskiej, Warszawa 2018).

33 Artykuł 189a § 2 k.p.a. 
ustawy o Rzeczniku do przepisów Działu IVa k.p.a. omówiona zostanie szczegółowo w dalszej części artykułu.

Poszukując zbliżonych sankcji nakładanych przez inne organy, można wskazać na kary pieniężne nakładane przez $\mathrm{KNF}^{34}$. W praktyce nie budzi wątpliwości, że kary te nakładane są na podstawie przepisów k.p.a., w formie decyzji administracyjnych, i podlegają następczej kontroli sądów administracyjnych ${ }^{35}$.

Podsumowując, stosowanie w związku z art. 32 ustawy o Rzeczniku przepisów k.p.a. i p.p.s.a. zapewnia podmiotom rynku finansowego konstytucyjne prawo do sądu i wiążące się z tym gwarancje procesowe ${ }^{36}$. Mimo generalnego domniemania kompetencji sądów powszechnych

${ }^{34}$ Chodzi o kary pieniężne nakładane m.in. na podstawie ustawy - Prawo bankowe, Ustawy z dnia 27 V 2004 r. o funduszach inwestycyjnych i zarządzaniu alternatywnymi funduszami inwestycyjnymi (tekst jedn. Dz.U. 2018, poz. 1355), Ustawy z dnia 29 VII 2005 r. o nadzorze nad rynkiem kapitałowym (tekst jedn. Dz.U. 2018, poz. 1417), dalej „ustawa o nadzorze nad rynkiem kapitałowym”, Ustawy z dnia 29 VII 2005 r. o obrocie instrumentami finansowymi (tekst jedn. Dz.U. 2017, poz. 1768), Ustawy z dnia 29 VII 2005 r. o ofercie publicznej i warunkach wprowadzania instrumentów finansowych do zorganizowanego systemu obrotu oraz o spółkach publicznych (tekst jedn. Dz.U. 2018, poz. 512), Ustawy z dnia 21 VII 2006 r. o nadzorze nad rynkiem finansowym (tekst jedn. Dz.U. 2018, poz. 621), dalej "ustawa o nadzorze nad rynkiem finansowym”, ustawy o działalności ubezpieczeniowej i reasekuracyjnej czy Ustawy z dnia 19 VIII 2011 r. o usługach płatniczych (tekst jedn. Dz.U. 2017, poz. 2003).

${ }^{35}$ Zob. wyrok NSA z 26 III 2009 r., sygn. II GSK 798/08, Legalis nr 220543; wyrok NSA z 16 IX 2010 r., sygn. II GSK 757/09, Legalis nr 269977; wyrok NSA z 17 IX 2013 r., sygn. II GSK 767/12, Legalis nr 794065; postanowienie NSA z 28 IV 2016 r., sygn. II GZ 957/15, Legalis nr 1467626; wyrok NSA z 2 II 2016 r., sygn. II GSK 2593/14, Legalis nr 1453907; wyrok NSA z 5 V 2016 r., sygn. II GSK 2962/14, Legalis nr 1511089; wyrok NSA z 26 IV 2017 r., sygn. II GSK 831/17, Legalis nr 1632410.

${ }^{36}$ Wcześniej, oczywiście, podmiot rynku finansowego będzie miał możliwość zwrócenia się do Rzecznika Finansowego z wnioskiem o ponowne rozpatrzenie sprawy (art. $127 \S 3$ k.p.a.). Wydaje się bowiem, że Rzecznik Finansowy może być kwalifikowany jako minister w rozumieniu art. 5 pkt 4 k.p.a. (bądź jako kierownik centralnego urzędu administracji rządowej podległy, podporządkowany lub nadzorowany przez Prezesa Rady Ministrów - wszak zgodnie z art. 11 ustawy o Rzeczniku Rzecznik Finansowy powoływany jest przez Prezesa Rady Ministrów na wniosek ministra właściwego do spraw instytucji finansowych), względnie jako „kierownik innych równorzędnych urzędów państwowych". W świetle art. 127 § 3 k.p.a. należałoby więc przyjąć, że od decyzji wydanej w pierwszej instancji przez Rzecznika Finansowego nie służy odwołanie, jednakże strona niezadowolona $\mathrm{z}$ decyzji może zwrócić się do tego organu z wnioskiem o ponowne rozpatrzenie sprawy; do wniosku tego stosuje się odpowiednio przepisy dotyczące odwołań od decyzji. Natomiast zgodnie z art. 52 \& 3 p.p.s.a.: "Jeżeli stronie przysługuje prawo do zwrócenia się do organu, który wydał decyzję z wnioskiem o ponowne rozpatrzenie sprawy, strona może wnieść skargę na tę decyzję bez skorzystania z tego prawa". 
wynikającego z art. 177 Konstytucji RP należałoby przyjąć, że w omawianym zakresie za właściwością sądów administracyjnych przemawia treść art. 184 ustawy zasadniczej. Również na tle art. 3 p.p.s.a. wskazuje się, że określony w tym przepisie zakres sądowej kontroli działalności administracji publicznej statuuje domniemanie jurysdykcji sądownictwa administracyjnego każdej aktywności podmiotu wykonywanej $\mathrm{w}$ prawnej formie działania administracji ${ }^{37}$.

\section{Kara pieniężna jako środek o charakterze ultima ratio}

Analizując problematykę nakładania kar pieniężnych na podstawie art. 32 ustawy o Rzeczniku, warto zaznaczyć, że przepis ten posługuje się terminem "może”, w związku z czym nałożenie kary pieniężnej mieści się w zakresie uznania administracyjnego Rzecznika Finansowego. W orzecznictwie wypowiadany jest pogląd, że stosowanie w przepisach kompetencyjnych wyrazu "może" oznacza, iż decyzje (w tym decyzje w przedmiocie nakładania kar pieniężnych) wydawane są w warunkach uznania administracyjnego - organ ma więc uprawnienie, nie zaś obowiązek do skorzystania z określonego środka prawnego ${ }^{38}$. W takiej sytuacji norma prawna nie reguluje zatem w sposób jednoznaczny i wyczerpujący warunków podjęcia aktu administracyjnego, a co za tym idzie, obowiązku określonego zachowania się organu, lecz przewiduje możliwość wyboru sposobu rozstrzygnięcia sprawy ${ }^{39}$. Inaczej mówiąc, instytucja uznania administracyjnego uprawnia odpowiedni organ do dyskrecjonalnego działania oraz do wydawania decyzji na podstawie nieokreślonych, a niekiedy niewymienionych w przepisach prawnych kryteriów ${ }^{40}$. Równocześnie dyskrecjonalność organu, a więc działanie w trybie uznania administracyjnego nie oznacza dowolności przy wydawaniu decyzji, bowiem organ winien wykazać, że w konkretnej sprawie istniały przesłanki uzasadniające podjęte rozstrzygnięcie ${ }^{41}$.

${ }^{37}$ J. Drachal, J. Jagielski, R. Stankiewicz, Komentarz do art. 3.

${ }^{38}$ Wyrok NSA z 4 III 2015 r., sygn. II GSK 200/14, LEX nr 1677586.

${ }^{39}$ B. Wojciechowski, Rozdziat X $\$ 42$ pkt IV ppkt 1, w: Wykładnia w prawie administracyjnym, seria System Prawa Administracyjnego, pod red. R. Hausera, A. Wróbla, Z. Niewiadomskiego, t. 4, Warszawa 2015.

${ }^{40}$ Ibidem.

${ }^{41}$ Wyrok NSA z 15 I 2016 r., sygn. I OSK 1382/14, LEX nr 2032712. Zob. też wyrok NSA z 8 I 2016 r., sygn. I OSK 1334/14, LEX nr 2032709, w którym NSA stwierdził, że „Uznania administracyjnego nie można oczywiście rozumieć jako dowolności organu 
W tym kontekście warto przywołać wyrok NSA z 2009 r., w którym sąd ten wskazał, że przy dokonywaniu sądowej kontroli zgodności z prawem wszelkich decyzji administracji o charakterze uznaniowym (a więc tam, gdzie ustawa daje organowi administracji możliwość dokonywania wartościowania i wyboru jednego spośród różnych dopuszczalnych w świetle prawa rozstrzygnięć) rola, zadania i zakres kompetencji niezawisłego sądu muszą być rozumiane znacznie szerzej i głębiej niż w innych sytuacjach ${ }^{42}$. Dlatego z decyzjami uznaniowymi zdaniem NSA - wiąże się nie zmniejszona, lecz zwiększona kontrola sądów, wykonywana z punktu widzenia legalności ${ }^{43}$. Wynika to z faktu,

w rozstrzygnięciu sprawy. Organ nie jest zwolniony z obowiązku przeprowadzenia pełnych i precyzyjnych ustaleń co do stanu faktycznego i oceny, czy okoliczności sprawy odpowiadają przesłankom udzielenia wnioskowanej pomocy. Uzasadniając wybór rozstrzygnięcia uznaniowego, organ musi przedstawić jasną i przekonującą argumentację zarówno co do faktów, jak i prawa. Uznając, że strona znajduje się w sytuacji, w której możliwe jest przyznanie pomocy w trybie wskazanym w ustawie, na organie ciąży obowiązek należytego wyjaśnienia, dlaczego w ramach uznania administracyjnego odmawia jednak jej udzielenia bądź udziela w wysokości niższej niż oczekiwana przez stronę. $Z$ tego względu inaczej jest ukształtowany zakres sądowej kontroli decyzji wydanych w ramach uznania administracyjnego. Sąd administracyjny nie rozstrzyga o tym, czy przyznać świadczenie i w jakiej wysokości, lecz bada, czy organ administracji publicznej wydał decyzję z zachowaniem przepisów postępowania. Kontroli sądu nie podlega zatem uznanie samo w sobie, ale poprawność postępowania dowodowego i wyciągniętych zeń wniosków co do tego, czy dany stan faktyczny uzasadnia przyznanie stronie świadczenia".

${ }^{42}$ Wyrok NSA z 6 X 2009 r., sygn. II GSK 53/09, LEX nr 573539. Zob. też wyrok NSA z 6 X 2009 r., sygn. II GSK 54/09, LEX nr 573540, oraz wyrok NSA z 6 X 2009 r., sygn. II GSK 55/09, LEX nr 571724.

${ }^{43}$ Wyrok NSA z 6 X 2009 r., II GSK 53/09, LEX nr 573539. Choć warto dodać, że w orzecznictwie sądów administracyjnych prezentowane jest również odmienne stanowisko. Przykładowo, w wyroku Wojewódzkiego Sądu Administracyjnego (WSA) w Warszawie z 22 VI 2007 r., sygn. VI SA/Wa 2198/06, LEX nr 355517, sąd ten stwierdził, że "Zaskarżona decyzja należy do kategorii decyzji uznaniowych. Kontrola legalności decyzji uznaniowych dokonywana przez sąd administracyjny ma ograniczony zakres. Sąd nie wnika w celowość wydania decyzji i rozstrzygnięcia w niej zawartego. Sprawdza, czy decyzję podjął właściwy organ, czy decyzja ma oparcie w przepisach prawa materialnego, czy organ nie przekroczył granic uznania administracyjnego, a więc, czy decyzja nie nosi znamion dowolności oraz czy organ uzasadnił rozstrzygnięcie sprawy przesłankami odnoszącymi się do strony. [...] Sądowa kontrola decyzji uznaniowej polega na zbadaniu, czy przed podjęciem decyzji organ dysponował niezbędnym materiałem dowodowym uzasadniającym rozstrzygnięcie sprawy i czy dokonał wszechstronnej oceny okoliczności faktycznych istotnych dla takiego rozstrzygnięcia. Jest to więc kontrola prawidłowości postępowania poprzedzającego wydanie decyzji i jego zgodności z art. 7, art. 77 § 1 i art. 80 k.p.a. [...] Decyzja uznaniowa może być uchylona przez Wojewódzki Sąd Administracyjny w wypadku stwierdzenia, że została wydana z takim naruszeniem przepisów o postępowaniu administracyjnym, które mogło mieć istotny wpływ na wynik sprawy 
że gdy większe są możliwości naruszenia lub nadużywania prawa, tam również kontrola sądowa musi być dokładniejsza i bardziej rygorystyczna, a uzasadnienie orzeczenia sądowego - jasne i niebudzące wątpliwości co do wyraźnie sprecyzowanych motywów (prawnych i nawet ocenianych $\mathrm{w}$ świetle prawa przesłanek pozaprawnych, jeśli tego rodzaju przesłanki legły u podstaw poddanej kontroli decyzji administracyjnej $)^{44}$. Argumentacja ta odnosiła się bezpośrednio do zakresu kontroli decyzji dokonywanej przez sądy administracyjne. Niemniej NSA w omawianym wyroku poruszył również kwestię tego, kiedy aktualizują się przesłanki uzasadniające wydanie decyzji w ramach uznania administracyjnego. Stwierdził, że taka decyzja powinna spełniać nie tylko wymóg zgodności z prawem materialnym i przepisami procesowymi przewidzianymi w k.p.a., ale także uwzględniać szeroko rozumiane kryterium racjonalności ingerencji organu w sferę prawną obywatela czy innego podmiotu prawa z punktu widzenia celów, jakie swym działaniem organ zamierza osiągnąc ${ }^{45}$. Oznacza to, że w odniesieniu do decyzji o charakterze uznaniowym, nakładającej na podmiot określoną sankcję, należałoby oczekiwać, aby powyższe względy, znajdujące wyraz w uzasadnieniu decyzji, były ukierunkowane na efektywne, ekonomiczne i najmniej uciążliwe dla otoczenia, a w szczególności adresata decyzji, urzeczywistnienie ustawowego zadania organu za pośrednictwem instrumentu prawnego będącego $w$ jego dyspozycji dla osiągnięcia zamierzonego i wymiernego rezultatu działania organu, przy uwzględnieniu interesu społecznego i rozważeniu słusznego interesu strony (art. 7 k.p.a.), a także oddziaływania organu na świadomość i kulturę prawną obywateli (art. 8 k.p.a.) ${ }^{46}$. W konsekwencji NSA stwierdził, że ze względu na charakter decyzji wydanej

(art. $145 \S 1$ pkt 1 lit. c) p.p.s.a.). O tego rodzaju naruszeniach można by mówić, gdy np. organ pozostawił poza swoimi rozważaniami argumenty podnoszone przez stronę, pominął istotne dla sprawy materiały dowodowe lub dokonał oceny tych materiałów wbrew zasadom logiki lub doświadczenia życiowego".

${ }^{44}$ Wyrok NSA z 6 X 2009 r., sygn. II GSK 53/09, LEX nr 573539.

${ }^{45}$ Ibidem. Zob. też wyrok NSA z 17 II 2010 r., sygn. II GSK 401/09, LEX nr 591926.

${ }^{46}$ Wyrok NSA z 6 X2009 r., sygn. II GSK 53/09, LEX nr 573539. NSA dodał też, że rozważenie istnienia podstawy dla wydania decyzji w ramach administracyjnego uznania, jaką jest decyzja nakładająca karę pieniężną, na kanwie rozpatrywanej sprawy „powinno być dokonane w pierwszej kolejności, przy wszechstronnym uwzględnieniu wyżej wskazanych kryteriów racjonalności ingerencji organu nadzoru w sferę prawną skarżącego, z punktu widzenia celów, jakie tym sposobem organ zamierza osiągnąć, w szczególności z uwzględnieniem interesów ubezpieczających, ubezpieczonych, uposażonych lub uprawnionych z umów ubezpieczenia". 
w ramach administracyjnego uznania, która uprawnia, a nie obliguje organ do podjęcia określonego rozstrzygnięcia, nie każdy przypadek analizowany pod tym kątem przez organ musi zostać sfinalizowany wydaniem pozostawionego ocenie organu rozstrzygnięcia - jednakże, jeżeli organ zdecyduje się na nie, to decyzja winna odpowiadać wymogowi racjonalności i efektywności ${ }^{47}$.

Powyższe oznacza, że mimo iż art. 32 ust. 1 ustawy o Rzeczniku uprawnia do nałożenia kary pieniężnej za delikt w postaci naruszenia obowiązków wynikających z przepisów ustawy o Rzeczniku w nim wskazanych, sam fakt obiektywnego ich naruszenia może być niewystarczający dla stwierdzenia zasadności wydania decyzji w przedmiocie nałożenia takiej kary. Konieczne może się okazać uzasadnienie przez Rzecznika racjonalności zastosowania takiego środka w kontekście celów, jakie stara się w ten sposób osiągnąć. Co do zasady więc, decyzja o nałożeniu kary pieniężnej stanowi środek o charakterze ultima ratio. Powinna zostać wydana wówczas, gdy inne - mniej inwazyjne - środki okażą się nieskuteczne.

Analiza orzecznictwa NSA prowadzi zatem do wniosku, że pojedyncze lub sporadyczne uchybienia przez podmioty rynku finansowego przepisom ustawy o Rzeczniku, bądź też uchybienia o niskim stopniu szkodliwości, mogą nie stanowić wystarczającej podstawy do skutecznego nałożenia na podstawie art. 32 ustawy o Rzeczniku kary pieniężnej, a więc takiej, która - w przypadku ewentualnej kontroli - nie zostałaby zmieniona lub uchylona przez sądy administracyjne. Wydaje się ponadto, że również w przypadku regularnych lub powtarzających się uchybień nałożenie kary co do zasady powinno być poprzedzone odpowiednio łagodniejszymi działaniami Rzecznika, zmierzającymi do uchylenia skutków naruszeń oraz do tego, aby w przyszłości nie następowały. Tym samym Rzecznik Finansowy, w przypadku podejrzenia, że podmiot rynku finansowego może naruszać określone przepisy (obowiązki) wynikające z ustawy o Rzeczniku, w pierwszej kolejności powinien się zwrócić do takiego podmiotu w celu uzyskania wyjaśnień w tym zakresie, a w razie konieczności, w celu jego upomnienia (ostrzeżenia). Takie działanie należałoby uznać za rodzaj sankcji o charakterze prewencyjnym $^{48}$. Tam, gdzie to możliwe, powinno również zmierzać

${ }^{47}$ Ibidem.

${ }^{48}$ Przykładowo, działanie Rzecznika Finansowego może zmierzać do tego, aby podmiot rynku finansowego zmienił określone elementy procedury rozpatrywania reklamacji. 
do naprawy negatywnych skutków, które wystąpiły ${ }^{49}$. Podstawę prawną takiego działania może stanowić art. 25 ust. 1 pkt 1 ustawy o Rzeczni$\mathrm{ku}$, natomiast obowiązek podmiotu rynku finansowego do udzielenia wyjaśnień w tym zakresie wynika z art. 31 tej ustawy. Wydaje się, że dopiero w sytuacji, w której podmiot rynku finansowego nie przedstawi stanowiska w sprawie, bądź też stanowisko to w ocenie Rzecznika Finansowego nadal uprawdopodobniać będzie przyszłe naruszenia przepisów ustawy o Rzeczniku, wszczęcie postępowania administracyjnego, a w konsekwencji ewentualne nałożenie kary pieniężnej może się okazać uzasadnione. W takich wypadkach określona kara pieniężna nakładana będzie więc za uchybienie określonemu przepisowi wskazanemu w art. 32 ust. 1 ustawy o Rzeczniku, na które składać się będzie wiele jednostkowych naruszeń podmiotu rynku finansowego. Warto przy tym dodać, że na tle rozpatrywanej problematyki „wielość naruszeń" może być rozumiana w dwóch płaszczyznach. Po pierwsze, jako wiele jednostkowych naruszeń jednego z przepisów (obowiązku wynikającego z przepisu) wskazanych w art. 32 ust. 1 ustawy o Rzeczniku. Po drugie, jako naruszenie (jednostkowe lub wielokrotne) więcej niż jednego przepisu, o których mowa w art. 32 ust. 1 ustawy o Rzeczniku.

Warto jednak wyraźnie zaznaczyć, że duża częstotliwość naruszeń określonego przepisu ustawy o Rzeczniku nie powinna stanowić koniecznej przesłanki nałożenia kary. Ta może się bowiem okazać uzasadniona również w przypadku jednostkowego naruszenia przez podmiot rynku finansowego określonego obowiązku w konkretnej indywidualnej sprawie danego klienta. Przykładowo, można sobie wyobrazić, że odpowiedź podmiotu rynku finansowego na reklamację rozpatrzoną niezgodnie $z$ wolą klienta nie zawiera należytego uzasadnienia faktycznego lub prawnego. Zresztą niejednokrotnie zdarza się, że odpowiedzi podmiotów rynku finansowego przygotowywane są "mechanicznie”, według określonych wzorców i nie dotykają istoty zastrzeżeń zgłaszanych przez klienta. Jeżeli w takich okolicznościach, mimo działań Rzecznika, klient nie otrzyma rzetelnej informacji, dlaczego jego reklamacja rozpatrzona została negatywnie, nałożenie kary może się okazać uzasadnione, mimo iż naruszenie przepisów ustawy o Rzeczniku miało miejsce w jednej indywidualnej sprawie klienta, a więc miało charakter jednostkowy.

${ }^{49}$ Przykładowo, działanie Rzecznika Finansowego może zmierzać do tego, aby podmiot rynku finansowego udzielił klientowi odpowiedzi na złożoną przez niego reklamację zgodnie z wymogami ustawy o Rzeczniku, bądź też szczegółowo wyjaśnił swoje negatywne stanowisko w korespondencji z Rzecznikiem Finansowym. 
Najczęściej jednak nałożenie kary będzie uzasadnione w przypadkach wielokrotnego naruszania przepisów ustawy o Rzeczniku.

Biorąc pod uwagę ratio legis przepisów ustawy o Rzeczniku, ingerencja Rzecznika materializująca się w decyzji nakładającej na podmiot rynku finansowego karę pieniężną uzasadniona może być w następujących okolicznościach. Oczywiście, po pierwsze, podmiot rynku finansowego obiektywnie musi naruszyć obowiązki wynikające z przepisów ustawy o Rzeczniku wskazanych w art. 32 ust. 1 tej ustawy. Po drugie natomiast, poprzez nałożenie kary Rzecznik Finansowy powinien dążyć do osiągnięcia konkretnych celów. W przypadku uchybień art. 4 ust. 1 oraz art. 6-10 ustawy o Rzeczniku chodzi o zapewnienie przestrzegania przez podmiot rynku finansowego szeroko rozumianych procedur związanych z rozpatrywaniem reklamacji. W szczególności chodzi o sytuacje, w których podmiot rynku finansowego mimo upomnień Rzecznika Finansowego kontynuuje - wadliwą w ocenie tego organu - praktykę stosowania przepisów ustawy o Rzeczniku. Natomiast w przypadku uchybień art. 30 i 31 ustawy o Rzeczniku nałożenie kary powinno zmierzać do zapewnienia przestrzegania przez podmioty rynku finansowego odpowiednich obowiązków w relacjach z Rzecznikiem Finansowym, tak aby organ ten mógł w sposób niezakłócony wykonywać nałożone na niego zadania. Chodzi więc o to, aby Rzecznik mógł rozpatrywać wnioski klientów, w indywidualnych sprawach, wnoszone na skutek nieuwzględnienia roszczeń przez podmiot rynku finansowego w trybie rozpatrywania reklamacji ${ }^{50}$, a także wnioski klientów dotyczące niewykonania czynności wynikających z reklamacji rozpatrzonej zgodnie z wolą klienta ${ }^{51}$, i w tym kontekście aby miał możliwość zbadania, czy mogło dojść do naruszenia jego praw lub interesów ${ }^{52}$.

W tym kontekście warto również przytoczyć treść art. 25 ust. 1 pkt 1 ustawy o Rzeczniku, który umożliwia Rzecznikowi występowanie do podmiotów rynku finansowego oraz innych podmiotów, których działalność wiąże się z rozpatrywaną sprawą, o udzielenie informacji lub wyjaśnień, udostępnienie akt oraz dokumentów. Uprawnienie to dotyczy spraw indywidualnych ${ }^{53}$, spraw postanowień wzorców umów,

\footnotetext{
${ }^{50}$ Artykuł 17 ust. 1 pkt 1 ustawy o Rzeczniku.

${ }^{51}$ Artykuł 17 ust. 1 pkt 2 ustawy o Rzeczniku.

${ }^{52}$ Artykuł 24 ust. 3 ustawy o Rzeczniku.

${ }^{53}$ Warto dodać, że zgodnie z art. 25 ust. 2 ustawy o Rzeczniku wystąpienie o udzielenie informacji lub wyjaśnień w sprawach indywidualnych może nastąpić wyłącznie za zgodą klienta, którego sprawa dotyczy.
} 
które według Rzecznika są niekorzystne dla klientów podmiotów rynku finansowego, spraw dotyczących wewnętrznych regulacji tych podmiotów rynku finansowego, które według Rzecznika są niekorzystne dla klientów, oraz spraw związanych z nieprawidłową obsługą klientów świadczoną przez podmioty rynku finansowego. Uniemożliwianie przez podmiot rynku finansowego realizacji uprawnień Rzecznika w tym zakresie, a w konsekwencji uchybienie treści art. 31 ustawy o Rzeczniku może uzasadniać nałożenie kary pieniężnej, której celem będzie wymuszenie przekazywania Rzecznikowi żądanych informacji i dokumentów. Ostatecznie zmierza to, oczywiście, do zapewnienia klientom podmiotów rynku finansowego ochrony - rozumianej zarówno wąsko, a więc poprzez działania podejmowane $\mathrm{w}$ indywidualnych sprawach klientów, jak i szeroko, np. poprzez informowanie o możliwych nieprawidłowościach odpowiednich organó $w^{54}$, w celu zbadania przez nie sprawy zgodnie $\mathrm{z}$ ich właściwością i kompetencjami ${ }^{55}$.

Upomnienie (ostrzeżenie) lub ponaglenie podmiotu rynku finansowego stanowi zatem również rodzaj sankcji, z tym że o charakterze niepieniężnym i raczej prewencyjnym. Natomiast sankcja w postaci administracyjnej kary pieniężnej ma charakter prewencyjno-represyjny. Co do zasady powinna więc stanowić środek o charakterze ultima ratio i mieć głębokie uzasadnienie merytoryczne, celowościowe oraz systemowe, tak aby utrzymana została w ewentualnej kontroli dokonywanej przez sądy administracyjne. $W$ przypadku podejrzenia, że podmiot rynku finansowego, mimo wcześniejszego upomnienia, narusza przepisy ustawy o Rzeczniku, a w szczególności jeżeli czyni to w sposób naganny lub uporczywy, powinno nastąpić wszczęcie postępowania administracyjnego w tym zakresie w celu ustalenia wszelkich istotnych okoliczności faktycznych oraz prawnych sprawy i w celu jej rozstrzygnięcia (nałożenia kary pieniężnej, odstąpienia od jej nałożenia lub umorzenia postępowania).

Powyższa analiza obrazuje również ogromną ułomność instrumentu, jakim jest kara pieniężna. Z pewnością stanowić będzie dla podmiotu rynku finansowego pewną dolegliwość, lecz w konkretnych okolicznościach nie pozwala na wyegzekwowanie wykonania obowiązków wynikających z ustawy o Rzeczniku, które na nim ciążyły (np. obowiązku przekazania Rzecznikowi określonych informacji lub dokumentów).

${ }^{54}$ W szczególności chodzi o Prezesa Urzędu Ochrony Konkurencji i Konsumentów (dalej „Prezes UOKiK”), KNF i prokuraturę.

${ }_{55}$ Artykuł 27 pkt 3 ustawy o Rzeczniku. 
Wówczas w istocie nie spełnia swojego celu. De lege ferenda warto więc rozważyć wprowadzenie mechanizmów (sankcji), które pozwoliłyby na skuteczne egzekwowanie wykonania tych obowiązków, np. na podstawie prawomocnego orzeczenia sądu.

\section{Podmiot rynku finansowego}

Nie powinno budzić wątpliwości, że kara pieniężna może zostać nałożona tylko i wyłącznie na podmiot rynku finansowego w rozumieniu art. 2 pkt 3 ustawy o Rzeczniku. Niemniej warto zauważyć, że zgodnie z treścią wspominanego już art. 25 ust. 1 pkt 1 ustawy o Rzeczniku możliwość wystąpienia przez Rzecznika lub upoważnionego przez niego pracownika o udzielenie informacji lub wyjaśnień, udostępnienie akt oraz dokumentów istnieje nie tylko wobec podmiotów rynku finansowego, ale również wobec innych podmiotów, których działalność wiąże się z rozpatrywaną sprawą. Literalna treść tego przepisu prowadzi zatem do wniosku, że Rzecznik Finansowy ma kompetencję do tego, aby podejmować działania i kierować korespondencję nie tylko do podmiotów rynku finansowego, ale również do innych podmiotów, którymi mogą być zarówno osoby fizyczne, osoby prawne, jak i osoby, o których mowa w art. $33^{1}$ Kodeksu cywilnego ${ }^{56}$, a które nie mają przymiotu podmiotu rynku finansowego $\mathrm{w}$ rozumieniu art. 2 pkt 3 ustawy o Rzeczniku.

Przykład może stanowić sytuacja, w której klient firmy inwestycyjnej za jej pośrednictwem nabywa obligacje korporacyjne określonego podmiotu. Firma inwestycyjna niewątpliwie będzie podmiotem rynku finansowego $\mathrm{o}^{57}$, zaś osoba fizyczna nabywająca obligacje jej klientem ${ }^{58}$. Wątpliwości budzi jednak, czy podmiotem rynku finansowego będzie również podmiot emitujący obligacje korporacyjne ${ }^{59}$, a w przypadku odpowiedzi twierdzącej, czy nabywców obligacji będzie można uznać za klientów w rozumieniu ustawy o Rzeczniku ${ }^{60}$. Przyjmując

\footnotetext{
${ }^{56}$ Ustawa z dnia 23 IV 1964 r. - Kodeks cywilny (Dz.U. 2018, poz. 1025), dalej „k.c.”.

${ }^{57}$ Artykuł 2 pkt 3 lit. e ustawy o Rzeczniku.

${ }^{58}$ Artykuł 2 pkt 1 lit. d ustawy o Rzeczniku.

${ }^{59}$ Zasady emisji obligacji uregulowane są w Ustawie z dnia 15 I 2015 r. o obligacjach (tekst jedn. Dz.U. 2018, poz. 483).

${ }^{60}$ Wątpliwości budzi m.in. to, czy emisja obligacji stanowi świadczoną klientowi przez podmiot rynku finansowego usługę, co do której nabywca obligacji może mieć zastrzeżenia (art. 2 pkt 2 ustawy o Rzeczniku).
} 
założenie, że emitent obligacji nie będzie - z samego faktu emisji obligacji - kwalifikowany jako podmiot rynku finansowego ${ }^{61}$, Rzecznik mimo to uprawniony będzie zwrócić się do takiego podmiotu na podstawie art. 25 ust. 1 pkt 1 ustawy o Rzeczniku, jeżeli jego działalność wiąże się $z$ rozpatrywaną sprawą.

Inny przykład może stanowić umowa kredytu wiązanego ${ }^{62}$. W świetle przepisów ustawy o kredycie konsumenckim jest to umowa o kredyt, na podstawie której kredytodawca ${ }^{63}$ udziela konsumentowi ${ }^{64}$ kredytu konsumenckiego ${ }^{65}$ na finansowane nabycia towaru lub usługi na podstawie umowy zawartej z innym podmiotem, gdy obie te umowy sa ze sobą powiązane. W takim wypadku Rzecznik Finansowy, działając na podstawie art. 25 ust. 1 pkt 1 ustawy o Rzeczniku, miałby prawo podjęcia działań nie tylko wobec kredytodawcy (podmiotu rynku finansowego), ale również wobec podmiotu, od którego konsument nabył towar lub usługę, a który co do zasady podmiotem rynku finansowego nie będzie.

Niemniej ustawa o Rzeczniku nie zawiera przepisu, który uzupełniałby uprawnienie Rzecznika w tym zakresie, a więc nakładał na takie podmioty (niebędące podmiotami rynku finansowego) obowiązek udzielenia Rzecznikowi odpowiedzi. Wszak hipoteza art. 31 ustawy o Rzeczniku, podobnie zresztą jak hipoteza art. 32 ustawy o Rzeczniku, obejmuje tylko i wyłącznie podmioty rynku finansowego, które zostały ściśle zdefiniowane w art. 2 pkt 3 tej ustawy. De lege lata kara pieniężna może więc zostać nałożona przez Rzecznika - mimo uprawnienia wynikającego z art. 25 ust. 1 pkt 1 ustawy o Rzeczniku - tylko i wyłącznie na podmiot rynku finansowego. De lege ferenda warto natomiast rozważyć rozszerzenie zakresu hipotezy art. 31 i 32 ustawy o Rzeczniku o podmioty, o których mowa w art. 25 ust. 1 pkt 1 tej ustawy, niebędące podmiotami rynku finansowego, których działalność wiąże się jednak

${ }^{61}$ Może mieć bowiem taki charakter niezależnie od faktu emisji obligacji, wszak obligacje mogą emitować również podmioty rynku finansowego, np. instytucje finansowe (art. 2 pkt 3 lit. b ustawy o Rzeczniku) czy instytucje pożyczkowe (art. 2 pkt 3 lit. h ustawy o Rzeczniku). Jednak nawet w takich przypadkach wątpliwości może budzić, czy $\mathrm{w}$ relacji podmiotu rynku finansowego z obligatariuszami, wynikającej z faktu emisji obligacji, zastosowanie znajdzie ustawa o Rzeczniku.

${ }_{62}$ Artykuł 5 pkt 14 Ustawy z dnia 12 V 2011 r. o kredycie konsumenckim (tekst jedn.

Dz.U. 2018, poz. 993), dalej „ustawa o kredycie konsumenckim”.

${ }^{63}$ Artykuł 5 pkt 2 ustawy o kredycie konsumenckim.

${ }^{64}$ Artykuł 5 pkt 1 ustawy o kredycie konsumenckim.

${ }^{65}$ Artykuły 2-4 ustawy o kredycie konsumenckim. 
$z$ rozpatrywaną przez Rzecznika sprawą. Powinno to zapewnić większą skuteczność działań podejmowanych przez Rzecznika Finansowego, a w konsekwencji lepszą ochronę klientów.

\section{Naruszenia przepisów ustawy o Rzeczniku skutkujące możliwością nałożenia kary pieniężnej}

Zgodnie z art. 32 ust. 1 ustawy o Rzeczniku kara pieniężna może zostać nałożona w przypadku naruszenia odpowiednio art. 4 ust. 1, art. 6-10, art. 30 i art. 31 ustawy o Rzeczniku. Należy przyjąć, że kara w wysokości do 100000 zł może zostać nałożona odrębnie za każde naruszenie (naruszenia) poszczególnych przepisów. Jeżeli podmiot rynku finansowego naruszył więcej niż jeden przepis wskazany w art. 32 ust. 1 ustawy o Rzeczniku i w każdym z tych przypadków nałożenie kary Rzecznik Finansowy uznaje za zasadne, to brak jest przeszkód, aby w jednej decyzji nałożyć odrębne kary cząstkowe za naruszenie lub naruszenia każdego z przepisów ${ }^{66}$. Oczywiście, powinny zostać one osobno szczegółowo uzasadnione. Ramy niniejszego opracowania nie pozwalają na odrębne omówienie każdego z tych przepisów w sposób dogłębny, niemniej warto zasygnalizować wybrane zagadnienia problemowe i niektóre aspekty budzące wątpliwości.

Po pierwsze, całkowicie niezrozumiały jest brak możliwości nałożenia kary w przypadku naruszenia przez podmioty rynku finansowego art. 4 ust. 2 ustawy o Rzeczniku. Cele tego przepisu są zbieżne z ratio legis art. 4 ust. 1 tej ustawy i zmierzają do zapewnienia klientowi prawdziwej, pełnej, rzetelnej i niewprowadzającej w błąd informacj ${ }^{67} \mathrm{w}$ przedmiocie

${ }^{66}$ Wówczas na mocy jednej decyzji administracyjnej nałożone zostaną kary za poszczególne naruszenia przez podmiot rynku finansowego określonych przepisów ustawy o Rzeczniku. Oznacza to, że decyzja nakładająca karę pieniężną może obejmować następujące sytuacje: (1) jednostkowe naruszenie wyłącznie jednego z przepisów wskazanych w art. 32 ust. 1 ustawy o Rzeczniku, (2) jednostkowe naruszenia więcej niż jednego przepisu wskazanego w art. 32 ust. 1 ustawy o Rzeczniku, (3) wielokrotne naruszenia jednego z przepisów wskazanych w art. 32 ust. 1 ustawy o Rzeczniku, (4) wielokrotne naruszenia więcej niż jednego przepisu wskazanego w art. 32 ust. 1 ustawy o Rzeczniku, a także (5) zarówno jednokrotne, jak i wielokrotne naruszenia przepisów wskazanych w art. 32 ust. 1 ustawy o Rzeczniku. Dodatkowo należy pamiętać, że jednostkowe działanie podmiotu rynku finansowego może oznaczać równoczesne naruszenie więcej niż jednego przepisu wskazanego w art. 32 ust. 1 ustawy o Rzeczniku.

${ }^{67}$ Zgodnie z art. 24 ust. 2 pkt 2 ustawy u.o.k.i.k.: „Przez praktykę naruszającą zbiorowe interesy konsumentów rozumie się godzące w nie sprzeczne z prawem lub dobrymi 
jego prawa do złożenia reklamacji. O ile art. 4 ust. 1 ustawy o Rzeczniku dotyczy umów, o tyle art. 4 ust. 2 tego aktu dotyczy takich sytuacji, w których klient zgłasza wobec podmiotu rynku finansowego roszczenia mimo braku umowy. Sytuacje takie zdarzają się w szczególności na rynku ubezpieczeniowym, gdzie roszczeń mogą dochodzić np. uposażeni, którzy nie są stroną umowy ubezpieczenia ${ }^{68}$. De lege ferenda warto więc rozważyć uzupełnienie dyspozycji art. 32 ust. 1 ustawy o Rzeczniku o naruszenie treści art. 4 ust. 2 tego aktu.

W odniesieniu do naruszenia art. 4 ust. 1 ustawy o Rzeczniku zbadania wymagać będzie natomiast, czy podmioty rynku finansowego $\mathrm{w}$ oferowanych i zawieranych $\mathrm{z}$ klientami umowach zamieszczają informacje dotyczące procedury składania i rozpatrywania reklamacji. Chodzi o to, aby informacje te w sposób prawdziwy, pełny, rzetelny i niewprowadzający klientów w błąd wskazywały miejsce i formę złożenia reklamacji, termin jej rozpatrzenia, a także sposób powiadomienia o rozpatrzeniu reklamacji.

Komentarza wymaga również treść art. 6 i 7 ustawy o Rzeczniku. Z przepisów tych wynika, że podmiot rynku finansowego powinien udzielić odpowiedzi na reklamację bez zbędnej zwłoki, jednak nie później niż w terminie 30 dni od dnia otrzymania reklamacji. Do zachowania tego terminu wystarczy wysłanie odpowiedzi przed jego upływem. Natomiast w szczególnie skomplikowanych przypadkach, uniemożliwiających rozpatrzenie reklamacji i udzielenie odpowiedzi w wyżej wskazanym 30-dniowym terminie, podmiot rynku finansowego powinien przekazać klientowi, który wystąpił z reklamacją, informację, w której wyjaśnia przyczynę opóźnienia, wskazuje okoliczności, które muszą zostać ustalone dla rozpatrzenia sprawy, i określa przewidywany termin rozpatrzenia reklamacji i udzielenia odpowiedzi, który nie może przekroczyć 60 dni od dnia otrzymania reklamacji.

Pewien problem może wynikać z faktu, że w przypadku wydłużenia terminu na udzielenie odpowiedzi na podstawie art. 7 ustawy

obyczajami zachowanie przedsiębiorcy, w szczególności: naruszanie obowiązku udzielania konsumentom rzetelnej, prawdziwej i pełnej informacji". Warto przy tym dodać, że regulacja ta odnosi się wyłącznie do konsumentów, podczas gdy klientem w rozumieniu ustawy o Rzeczniku może być również osoba fizyczna niebędąca konsumentem (art. 2 pkt 1 ustawy o Rzeczniku).

${ }^{68} \mathrm{Na}$ marginesie warto zaznaczyć, że w świetle treści art. 4 ust. 2 ustawy o Rzeczniku klientem podmiotu rynku finansowego, a więc osobą mogącą korzystać ze wszystkich uprawnień wynikających z tej ustawy, może być osoba fizyczna, której z podmiotem rynku finansowego bezpośrednio nie łączy żadna umowa. 
o Rzeczniku ani ten przepis (który jedynie nakłada obowiązek przekazania klientowi określonych informacji), ani też art. 6 wskazanego aktu (który nakłada obowiązek udzielenia odpowiedzi na reklamacje w terminie 30 dni od dnia jej otrzymania) nie przewidują explicite obowiązku podmiotu rynku finansowego udzielenia odpowiedzi w terminie 60 dni od dnia otrzymania reklamacji. Ratio legis omawianych norm prowadzi jednak do wniosku, że uchybienie 60-dniowemu terminowi wynikającemu z art. 7 ustawy o Rzeczniku (podobnie jak uchybienie 30-dniowemu terminowi wynikającemu z art. 6 ustawy o Rzeczniku, gdy podmiot rynku finansowego go nie wydłuża), oznaczać będzie naruszenie, które może stanowić podstawę do nałożenia kary pieniężnej na podstawie art. 32 ustawy o Rzeczniku. Za takim stanowiskiem przemawia również treść art. 8 ustawy o Rzeczniku, który "sankcjonuje” zarówno niedochowanie 30-dniowego terminu wynikającego z art. 6 ustawy o Rzeczniku, jak i ewentualnego terminu 60-dniowego wynikającego $\mathrm{z}$ art. 7 tej ustawy.

W odniesieniu do art. 7 ustawy o Rzeczniku naruszenie tego przepisu może również polegać na nieprzekazaniu klientowi wskazanych w jego pkt 1-3 informacji bądź na przekazaniu ich w sposób nieprawdziwy, niepełny, nierzetelny lub wprowadzający klienta w błąd - oczywiście wówczas, gdy podmiot rynku finansowego wydłuża termin na rozpatrzenie reklamacji. Problemy interpretacyjne oraz dowodowe mogą się natomiast pojawić w związku z koniecznością ustalenia, kiedy zachodzi „szczególnie skomplikowany przypadek, uniemożliwiający rozpatrzenie reklamacji w terminie $30 \mathrm{dni}$ od dnia jej otrzymania". W praktyce moga się też pojawić wątpliwości, czy podmiot rynku finansowego należycie wyjaśnił przyczynę opóźnienia oraz czy wskazał wszelkie okoliczności, które musi ustalić w celu rozpatrzenia sprawy. Kwestie te mają charakter wysoce ocenny i w pierwszej kolejności ustalane są przez podmiot rynku finansowego. Podlegają natomiast kontroli ze strony Rzecznika Finansowego, w kontekście możliwości nałożenia kary pieniężnej mieszczą się jednak w ramach uznania administracyjnego. Tym samym skuteczne nałożenie kary w tym zakresie w praktyce może się okazać niezwykle trudne.

Najbardziej problematyczna może się okazać kompetencja do nakładania kary pieniężnej w związku z naruszeniem art. 8 ustawy o Rzeczniku. Nie wchodząc szczegółowo w problemy interpretacyjne związane z tym przepisem, warto w tym miejscu zasygnalizować, że może być on rozpatrywany jako ustanawiający wzruszalne domniemanie 
prawne $^{69}$ bądź też jako fikcja prawna ${ }^{70}$. Ma to z kolei kluczowe znaczenie dla ustalenia, w jakich okolicznościach Rzecznik Finansowy na podstawie tego przepisu może nakładać karę pieniężną.

Przyjęcie, że mowa jest o domniemaniu wzruszalnym, skłaniałoby do poglądu, że kara pieniężna mogłaby zostać nałożona najwcześniej w przypadku wydania prawomocnego orzeczenia sądu powszechnego uwzględniającego powództwo klienta. Wcześniej Rzecznik Finansowy nie miałby bowiem pewności, czy domniemanie nie zostanie wzruszone przez sąd ${ }^{71}$. Przyjęcie odmiennego poglądu oznaczałoby z kolei, że w istocie Rzecznik Finansowy obowiązany byłby merytorycznie rozpatrywać spór między podmiotem rynku finansowego a jego klientem. W przypadku uznania, że roszczenie klienta jest zasadne, a zarazem że podmiot rynku finansowego - mimo treści art. 8 ustawy o Rzeczniku nie spełnia roszczenia klienta, aktualizowałaby się możliwość nałożenia kary. Taki pogląd jest jednak trudny do przyjęcia z kilku powodów.

${ }^{69} \mathrm{~W}$ ujęciu pozanormatywnym domniemanie można rozumieć jako uprawdopodobnienie pewnych faktów, co do których nie ma pewności, czy są prawdziwe, jednak wiele przemawia za tym, by je za takie uznać. Domniemanie prawne nakazuje natomiast przyjąć określony fakt za udowodniony (wniosek domniemania), jeśli został ustalony (udowodniony) inny fakt (przesłanka domniemania). Domniemanie wzruszalne może być obalone przez dowód przeciwny, co oznacza, że należy udowodnić nieistnienie faktów domniemanych (wniosku domniemania) bądź faktów, które stanowią podstawę domniemania (przesłanki domniemania). Domniemanie prawne formalne nie zawiera natomiast podstawy, lecz przewiduje nakaz przyjęcia określonego stanu faktycznego za istniejący dopóty, dopóki nie zostanie udowodnione, że tak nie jest, np. domniemanie dobrej wiary (art. 7 k.c.).

${ }^{70}$ Fikcja prawna zachodzi wtedy, gdy przepis prawa (norma prawna) nakazuje uznanie wystąpienia pewnego faktu prawnego, który w rzeczywistości nie miał miejsca (lub uznanie niewystąpienia faktu, który w rzeczywistości miał miejsce), z czym wiążą się określone skutki prawne. Przykład fikcji stanowi art. $44 \S 4$ k.p.a. (fikcja prawna doręczenia). Zob. D. Hamerlak, M. Drewiany, Fikcja prawna doręczenia w postępowaniu administracyjnym prowadzonym przez organy publiczne, "Zeszyty Naukowe WSFiP” 2014, nr 2, http://www.wsfip.edu.pl/docs/biezacynumer/ZN2_2014/ZN_WSFiP_2_2014_5_Hamerlak_Dorota_Drewniany_Magdalena.pdf (dostęp: 5 V 2018).

${ }^{71} \mathrm{~W}$ takim przypadku dalsze wątpliwości może budzić kwestia, czy w kontekście możliwości nałożenia kary pieniężnej orzeczenie powinno być oparte na podstawie art. 8 ustawy o Rzeczniku. Innymi słowy, nie jest jasne, czy jeżeli sąd uwzględni wprawdzie powództwo klienta wniesione przeciwko podmiotowi rynku finansowego, lecz nie uczyni tego na podstawie art. 8 ustawy o Rzeczniku (bądź też nie powoła się explicite na ten przepis w uzasadnieniu orzeczenia), ewentualne nałożenie kary pieniężnej na podmiot rynku finansowego byłoby dopuszczalne. Oczywiście, chodzi o sytuacje, w których podmiot rynku finansowego przed wniesieniem powództwa nie rozpatrzył reklamacji zgodnie z art. 6 i 7 ustawy o Rzeczniku i nie spełniał roszczeń klienta. Wątpliwości mogą się również pojawić w sytuacji, w której to podmiot rynku finansowego pozwie klienta. 
Po pierwsze, może być rozpatrywany jako niedopuszczalna ingerencja Rzecznika Finansowego w uprawnienia władzy sądowniczej. Po drugie, Rzecznik Finansowy nie posiada odpowiedniego instrumentarium - na wzór przepisów Kodeksu postępowania cywilnego ${ }^{72}$ - pozwalającego na rozpatrywanie tego rodzaju sporów, mających stricte cywilnoprawny charakter $^{73}$. Zresztą nie taka jest jego rola.

Przyjmując natomiast, że art. 8 ustawy o Rzeczniku wprowadza fikcję prawna, nałożenie kary możliwe byłoby w tych przypadkach, w których podmioty rynku finansowego nie spełniałyby roszczeń klientów zgodnie z ich wola, wynikającą z nierozpatrzonej lub nienależycie rozpatrzonej w ustawowych terminach reklamacji.

Na marginesie warto zaznaczyć, że niezależnie od tego, który wariant interpretacyjny uznać za słuszny ${ }^{74}$, bardzo często ustalenie woli klienta, a tym bardziej treści i zakresu jego roszczenia na podstawie samej tylko

${ }^{72}$ Ustawa z dnia 17 listopada 1964 r. - Kodeks postępowania cywilnego (tekst jedn. Dz.U. 2018, poz. 1360).

${ }^{73}$ Oczywiście, rozpatrując wnioski klientów o zbadanie sprawy, wnioski o wydanie istotnego poglądu bądź też wnioski o wniesienie skargi nadzwyczajnej, Rzecznik Finansowy w sposób oczywisty przyjmuje pewne założenia i określony stan faktyczny, następnie dokonując zarówno oceny tego stanu faktycznego (faktów), jak i oceny (wykładni) przepisów prawa. Niemniej ustalenia i oceny Rzecznika nie są dla sądów ani innych organów wiążące.

${ }^{74} \mathrm{~W}$ tym kontekście warto zaznaczyć, że do SN skierowane zostało następujące zagadnienie prawne: „Czy w procesie z powództwa klienta przeciwko podmiotowi rynku finansowego o zapłatę kwoty roszczenia zgłoszonej w reklamacji klienta, regulacja zawarta w art. 8 ustawy z dnia 5 sierpnia 2015 roku o rozpatrywaniu reklamacji przez podmioty rynku finansowego i o Rzeczniku Finansowym (Dz.U. z 2016 roku, poz. 892, t. jedn. ze zm.) wyłącza możliwość kwestionowania przez podmiot rynku finansowego zasadności dochodzonego roszczenia tak co do zasady, jak i co do wysokości, czy jedynie oznacza przerzucenie ciężaru dowodu na podmiot rynku finansowego, który będzie zobowiązany udowodnić, że roszczenie nie przysługuje powodowi bądź przysługuje mu w niższej wysokości?" (sygn. III CZP 113/17, postanowienie Sądu Okręgowego w Lublinie z dnia 12 VII 2017 r., sygn. II Ca 99/17), http://www.sn.pl/sprawy/SitePages/e-Sprawa.aspx?ItemSID $=10081$-ce0d61b0=-f80-4050--be5-582-c7606c5ea\&ListName=espraw2017a\&SearchIII\%20CZP\%20113/17 (dostęp: 5 V 2018).

W uchwale z 13 VI 2018 r., sygn. III CZP 113/17, SN wskazał, że „W postępowaniu wszczętym przez klienta przeciwko podmiotowi rynku finansowego o zapłatę kwoty roszczenia zgłoszonej w reklamacji klienta, art. 8 ustawy z dnia 5 sierpnia 2015 r. o rozpatrywaniu reklamacji przez podmioty rynku finansowego i o Rzeczniku Finansowym (tekst jedn. Dz.U. z 2017 r., poz. 2270) nie wyłącza możliwości kwestionowania przez podmiot rynku finansowego zasadności dochodzonego roszczenia; na podmiocie tym spoczywa ciężar dowodu, że powodowi nie przysługuje roszczenie lub przysługuje w niższej wysokości", http://www.sn.pl/sites/orzecznictwo/Orzeczenia3/III\%20CZP\%20 113-17-2.pdf (dostęp: 10 VII 2018). 
treści reklamacji może się okazać bardzo trudne. W efekcie w przypadku nierozpatrzenia lub nienależytego rozpatrzenia przez podmiot rynku finansowego takiej reklamacji może się pojawić problem, w jaki sposób stosować art. 8 ustawy o Rzeczniku, a w konsekwencji wątpliwość, czy w takich okolicznościach możliwe jest nałożenie kary na podstawie art. 32 tej ustawy.

Nie powinna natomiast budzić większych wątpliwości kwestia nakładania kar pieniężnych za naruszenia art. 9 i 10 ustawy o Rzeczniku. Przepisy te nakładają na podmioty rynku finansowego ściśle określone obowiązki informacyjne w związku z udzielaniem odpowiedzi na reklamację. Artykuł 9 tej ustawy przewiduje zakres informacji, jakie powinny się znaleźć w takiej odpowiedzi niezależnie od tego, czy uwzględnia ona roszczenia klienta czy też nie. Wyjątek stanowi obowiązek formułowania przez podmiot rynku finansowego uzasadnienia faktycznego i prawnego, który dezaktualizuje się, gdy reklamacja zostaje rozpatrzona zgodnie z wolą klienta ${ }^{75}$. Natomiast art. 10 ustawy o Rzeczniku przewiduje zakres informacji i pouczeń, jakie powinny się znaleźć w odpowiedzi na reklamację, gdy podmiot rynku finansowego nie uwzględnia wynikających z niej roszczeń. Naruszenie tych przepisów nastąpi w przypadku nieprzekazania klientowi wskazanych w nich informacji bądź w przypadku przekazania ich w sposób nieprawdziwy, niepełny, nierzetelny lub wprowadzający klienta w błąd.

Podobnie stosowanie art. $32 \mathrm{w}$ zw. z art. 30 ustawy o Rzeczniku nie powinno budzić większych wątpliwości. Na podstawie art. 30 tej ustawy podmiot rynku finansowego na wniosek Rzecznika obowiązany jest przekazać wzorzec umowy o świadczenie usług, którym posługuje się w swojej działalności, oraz inne dokumenty i formularze stosowane przy zawieraniu i wykonywaniu tych umów, w terminie 14 dni od dnia otrzymania wniosku. Oczywiście, wykładni wymagać będzie, co należy rozmieć pod pojęciem wzorca umownego ${ }^{76} \mathrm{czy}_{\text {formularza }}{ }^{77}$.

${ }^{75}$ Artykuł 9 pkt 1 ustawy o Rzeczniku.

${ }^{76}$ Zgodnie z art. 384 § 1 k.c. „Ustalony przez jedną ze stron wzorzec umowy, w szczególności ogólne warunki umów, wzór umowy, regulamin, wiąże drugą stronę, jeżeli został jej doręczony przed zawarciem umowy". W szczególności wątpliwości może jednak budzić, czy podmiot rynku finansowego obowiązany jest przekazać wzorce umowne sensu stricto, czy też konkretne (oczywiście zanonimizowane) umowy zawarte na podstawie takich wzorców.

${ }^{77}$ Wydaje się, że można przez to rozumieć np. formularz informacyjny, o którym mowa w art. 14 ustawy o kredycie konsumenckim, czy art. 11 ust. 2 Ustawy z dnia 23 marca 2017 r. o kredycie hipotecznym oraz o nadzorze nad pośrednikami kredytu 
Niemniej nie powinno budzić wątpliwości, że uchybienie temu przepisowi polegać będzie na nieprzekazaniu, nieterminowym przekazaniu bądź też przekazaniu w niepełnym zakresie żądanych przez Rzecznika informacji. Warto dodać, że omawianą kompetencję Rzecznika należy ocenić jako szczególną, gdyż pozwala ona na prewencyjne badanie stosowanych przez podmioty rynku finansowego wzorców umów i innych dokumentów pod kątem ich zgodności z obowiązującymi normami i wykrywanie ewentualnych nieprawidłowości. Uchybienie przez podmiot rynku finansowego normie wynikającej z omawianego przepisu z założenia należy więc uznać za szczególnie naganne.

Trudności interpretacyjne może natomiast powodować treść art. 31 ustawy o Rzeczniku. Z przepisu tego wynika, że podmiot rynku finansowego, który otrzymał wniosek Rzecznika w sprawach objętych zakresem jego działalności, obowiązany jest niezwłocznie, nie później niż w terminie 30 dni od dnia otrzymania wniosku, poinformować Rzecznika o podjętych działaniach lub zajętym stanowisku oraz przekazać żądane dokumenty. Przepis ten zasadniczo koresponduje z pozostałymi przepisami ustawy o Rzeczniku (w szczególności z jej art. 17, art. 24, art. 25 oraz art. 27 pkt 2). Wydaje się też, że może znaleźć zastosowanie do korespondencji Rzecznika kierowanej do podmiotów rynku finansowego $\mathrm{w}$ ramach pozasądowego postępowania w sprawie rozwiązywania sporów między klientem a podmiotem rynku finansowego uregulowanego w Rozdziale 4 ustawy o Rzeczniku. Niemniej dyspozycja art. 31 ustawy o Rzeczniku nie została, niestety, w sposób precyzyjny skorelowana z wyżej wskazanymi przepisami. Przykładowo, na podstawie omawianego już wcześniej art. 25 ust. 1 pkt 1 ustawy o Rzeczniku Rzecznik może występować do podmiotów rynku finansowego oraz innych podmiotów, których działalność wiąże się z rozpatrywaną sprawa, o udzielenie informacji lub wyjaśnień, udostępnienie akt oraz dokumentów. Tymczasem w art. 31 ustawy o Rzeczniku mowa jest jedynie o tym, że podmiot rynku finansowego obowiązany jest poinformować Rzecznika o podjętych działaniach lub zajętym stanowisku oraz przekazać żądane dokumenty. Z literalnego jego brzmienia nie wynika więc, aby na podmiotach rynku finansowego ciążył obowiązek przekazywania Rzecznikowi żądanych informacji, wyjaśnień czy

hipotecznego i agentami (Dz.U. 2017, poz. 819), dalej „ustawa o kredycie hipotecznym”. Jednak również w tym przypadku wątpliwości może budzić, czy Rzecznik uprawniony jest żądać (zanonimizowanych) formularzy informacyjnych dotyczących konkretnych konsumentów. 
akt, o które Rzecznik może wystąić na podstawie art. 25 ust. 1 pkt 1 ustawy o Rzeczniku. Ścisła wykładnia tych przepisów mogłaby zatem prowadzić do wniosku, że wystarczy poinformowanie Rzecznika o zajętym stanowisku lub podjętych działaniach. Warto także zaznaczyć, że obecnie niektóre podmioty rynku finansowego przekazują Rzecznikowi Finansowemu jedynie ogólną informację o podjętych działaniach lub też kopię stanowiska (odpowiedzi na reklamację) wysłanych do klientów, nie przekazując Rzecznikowi w sposób precyzyjny żądanych informacji czy wyjaśnień. Oczywiście ratio legis art. 31 w zw. z art. 25 ust. 1 pkt 1 ustawy o Rzeczniku prowadzi do wniosku, że na podmiotach rynku finansowego ciąży obowiązek przekazania nie tylko żądanych dokumentów, ale również wszelkich żądanych informacji, wyjaśnień lub akt. Niewykonanie, a także nieterminowe lub nienależyte wykonanie tego obowiązku stanowi zaś naruszenie art. 31 ustawy o Rzeczniku i w konsekwencji może uzasadniać nałożenie kary pieniężnej. Jedynie taka wykładnia omawianych przepisów pozwalać będzie Rzecznikowi na skuteczne wykonywanie wynikających z ustawy o Rzeczniku zadań i umożliwia realizację podstawowego obowiązku Rzecznika, polegającego na badaniu, czy podmiot rynku finansowego naruszył prawa lub interesy klienta. Niemniej nie sposób wykluczyć, że przepisy te, w kontekście art. 32 ustawy o Rzeczniku, wykładane będą przez sądy administracyjne wąsko, a więc zgodnie $\mathrm{z}$ ich literalnym brzmieniem i zgodnie z zasadą nullum crimen sine lege certa. Nie budzi natomiast wątpliwości obowiązek przekazania dokumentów, gdy Rzecznik wnosi o ich udostępnienie, choć $\mathrm{w}$ praktyce $\mathrm{w}$ tym zakresie podmioty rynku finansowego niekiedy odmawiają ich przekazania, powołując się np. na konieczność ochrony tajemnicy przedsiębiorstwa ${ }^{78}$.

${ }^{78}$ Artykuł 11 ust. 4 Ustawy z dnia 16 IV 1993 r. o zwalczaniu nieuczciwej konkurencji (tekst jedn. Dz.U. 2018, poz. 419), dalej „ustawa o zwalczaniu nieuczciwej konkurencji". W tym kontekście warto zaznaczyć, że żaden przepis ustawy o Rzeczniku nie daje podmiotowi rynku finansowego prawa do odmówienia przekazania Rzecznikowi Finansowemu żądanych dokumentów (bez względu na okoliczności). Analogicznie, zgodnie z art. 50 ust. 1 ustawy u.o.k.i.k.: „Przedsiębiorcy są obowiązani do przekazywania wszelkich koniecznych informacji i dokumentów na żądanie Prezesa Urzędu". Na tle tego przepisu w doktrynie przyjmuje się, że podstawą do odmowy udzielenia informacji Prezesowi UOKiK nie może być powołanie się przez przedsiębiorcę na tajemnicę przedsiębiorstwa (Komentarz do art. 50, w: Ustawa o ochronie konkurencji i konsumentów. Komentarz, pod red. T. Skocznego, Warszawa 2014). Warto też dodać, że do czynności podejmowanych przez Rzecznika w trybie art. 25 ust. 1 pkt 1 ustawy o Rzeczniku nie mają zastosowania przepisy k.p.a., w tym art. $73 \S 1$ k.p.a. przyznający stronie prawo wglądu do akt sprawy. Natomiast w odniesieniu do dostępu do informacji publicznej, 
De lege ferenda należałoby więc rozważyć zmianę treści art. 31 ustawy o Rzeczniku, tak aby nie budziło wątpliwości, że podmiot rynku finansowego (lub inny podmiot, którego działalność wiąże się z rozpatrywaną sprawą), który otrzymał wniosek Rzecznika w sprawach objętych zakresem jego działalności, nie tylko obowiązany jest poinformować Rzecznika o podjętych działaniach lub zajętym stanowisku i udostępnić żądane dokumenty, ale nadto że jest również obowiązany przekazać wszelkie żądane przez Rzecznika informacje, wyjaśnienia, formularze lub akta ${ }^{79}$.

\section{Stosowanie przepisów Działu IVa k.p.a.}

Zgodnie z art. 32 ust. 2 ustawy o Rzeczniku przy ustalaniu wysokości kary pieniężnej należy uwzględnić stopień naruszenia przepisów, okoliczności tego naruszenia oraz możliwości finansowe podmiotu, który dokonał naruszenia. Przepis ten reguluje więc przesłanki wymiaru administracyjnej kary pieniężnej. W tym zakresie nie znajdą zatem zastosowania niektóre przepisy Działu IV k.p.a. ${ }^{80} \mathrm{~W}$ szczególności chodzi o treść art. 189d k.p.a., aczkolwiek wątpliwości może budzić to, czy wszystkie wskazane w tym przepisie przesłanki określają stopień naruszenia przepisów lub okoliczności tego naruszenia.

art. 5 ust. 1 u.o.d.i.p. stanowi, że prawo do informacji publicznej podlega ograniczeniu w zakresie i na zasadach określonych w przepisach o ochronie informacji niejawnych oraz o ochronie innych tajemnic ustawowo chronionych, a zatem również tajemnicy przedsiębiorstwa, co wynika zresztą wprost z art. 5 ust. 2 zd. 1 tego aktu. Wreszcie, zgodnie z art. 32a ust. 1 ustawy o Rzeczniku, pracownicy Biura Rzecznika są obowiązani do ochrony tajemnicy przedsiębiorstwa w rozumieniu art. 11 ust. 4 ustawy o zwalczaniu nieuczciwej konkurencji oraz innych informacji podlegających ochronie na podstawie odrębnych przepisów, o których powzięli wiadomość w związku z czynnościami wykonywanymi na podstawie ustawy o Rzeczniku. Przepisu tego nie stosuje się jedynie do informacji powszechnie dostępnych, informacji o wszczęciu postępowania oraz informacji o wydaniu decyzji kończących postępowanie i ich ustaleniach (art. 32a ust. 2 ustawy o Rzeczniku). Powyższe przemawia za przyjęciem, że co do zasady podmioty rynku finansowego nie są uprawnione do odmawiania przekazania żądanych przez Rzecznika dokumentów.

${ }^{79}$ Proponowana treść art. 31 ustawy o Rzeczniku: „Podmiot rynku finansowego lub inny podmiot, którego działalność wiąże się z rozpatrywaną sprawą, który otrzymał wniosek Rzecznika w sprawach objętych zakresem jego działalności, jest obowiązany niezwłocznie, nie później niż w terminie 30 dni od dnia otrzymania wniosku, poinformować Rzecznika o podjętych działaniach lub zajętym stanowisku oraz przekazać wszelkie żądane przez Rzecznika informacje, wyjaśnienia, dokumenty lub formularze, a także udostępnić akta".

${ }^{80}$ Artykuł 189a § 2 k.p.a. 
Przykładowo, nie jest jasne, czy ewentualne działania podmiotu rynku finansowego podjęte dobrowolnie w celu uniknięcia skutków naruszenia prawa stanowią okoliczności naruszenia prawa sensu stricto. Przyjmując, że nie stanowią takiej okoliczności, art. 189d pkt 5 k.p.a. mógłby znaleźć zastosowanie do kary pieniężnej nakładanej na podstawie art. 32 ustawy o Rzeczniku (nie byłaby to bowiem kwestia uregulowana w art. 32 ustawy o Rzeczniku). Niemniej szeroka wykładnia art. 189d pkt 5 k.p.a. może prowadzić do wniosku, że działania podmiotu rynku finansowego zmierzające do zminimalizowania lub uchylenia negatywnych skutków działania naruszającego przepisy ustawy o Rzeczniku ściśle związane są z okolicznościami naruszenia (bądź też że taką okoliczność stanowią). Wyłączałoby to możliwość stosowania tego przepisu w związku z karami nakładanymi na podstawie art. 32 ustawy o Rzeczniku.

Również część przesłanek wskazanych w art. 189d pkt 1 k.p.a., tj. potrzeba ochrony życia lub zdrowia, ochrony mienia w znacznych rozmiarach lub ochrony ważnego interesu publicznego bądź wyjątkowo ważnego interesu strony, zdaje się nie określać okoliczności naruszenia prawa - choć literalne brzmienie tego przepisu sugeruje odmienny wniosek, przesłanki te bowiem wymienione zostały jako egzemplifikacja „wagi i okoliczności naruszenia prawa”. Natomiast czas trwania naruszenia prawa (art. 189d pkt 1 in fine k.p.a.), częstotliwość niedopełniania w przeszłości obowiązku albo naruszania zakazu tego samego rodzaju co niedopełnienie obowiązku albo naruszenie zakazu, w następstwie którego ma być nałożona kara (art. 189d pkt 2 k.p.a.), stopień przyczynienia się podmiotu rynku finansowego, na który nakładana jest administracyjna kara pieniężna, do powstania naruszenia prawa (art. 189d pkt 4 k.p.a.) i wysokość korzyści, którą podmiot rynku finansowego osiągnął, lub straty, której uniknął (art. 189d pkt 6 k.p.a.), określają okoliczności lub stopień naruszenia prawa. Jakkolwiek oznaczałoby to, że przepisy te nie mogą być wprost stosowane do kar pieniężnych nakładanych na podstawie art. 32 ustawy o Rzeczniku, to równocześnie wydaje się, że można się nimi posiłkować przy wykładni art. 32 ust. 2 tego aktu. Wszak okoliczności określone w art. 189d pkt 1 in fine, 2, 4 i 6 k.p.a. mogą być rozpatrywane jako objęte dyspozycją art. 32 ust. 2 ustawy o Rzeczniku (stopień naruszenia przepisów lub okoliczności tego naruszenia). Natomiast w odniesieniu do art. 189d pkt 3 i 7 k.p.a. można sądzić, że przepisy te $\mathrm{z}$ istoty nie znajdą zastosowania do kar pieniężnych nakładanych na podstawie art. 32 ustawy o Rzeczniku. 
Treść art. 189d k.p.a. może zresztą budzić dalsze wątpliwości. Literalne brzmienie tego przepisu może bowiem prowadzić do wniosku, że obejmuje on przesłanki nałożenia kary pieniężnej jako takiej, nie zaś wysokości takiej kary. Tymczasem w art. 32 ust. 2 ustawy o Rzeczniku mowa jest nie tyle o przesłankach nałożenia kary pieniężnej (przesłanką w tym zakresie jest naruszenie przepisów ustawy o Rzeczniku wskazanych w jej art. 32), lecz o przesłankach określających zasady ustalania wymiaru (wysokości) nakładanej kary. Wydaje się jednak, że art. 189d k.p.a. w głównej mierze określa przesłanki ustalania wysokości kary. Znajduje więc zastosowanie wówczas, gdy ze względu na obiektywne naruszenie określonych obowiązków lub zakazów wynikających z przepisów materialnego prawa administracyjnego nałożenie kary pieniężnej będzie uzasadnione celami, jakie organ stara się w ten sposób osiągnąć. Służy więc miarkowaniu ostatecznej wysokości kary.

Artykuł 32 ust. 2 ustawy o Rzeczniku wprowadza natomiast dodatkową - nieprzewidzianą w przepisach k.p.a. - przesłankę, jaką Rzecznik ma obowiązek uwzględniać przy ustalaniu wysokości nakładanej kary pieniężnej. Chodzi o możliwości finansowe podmiotu rynku finansowego, który dopuścił się naruszenia odpowiednich przepisów ustawy o Rzeczniku. Przesłankę tę należy uznać ze wszech miar za słuszna, wszak kary pieniężne nie powinny narażać stabilności finansowej i wypłacalności podmiotów karanych. W postępowaniu administracyjnym prowadzonym na podstawie art. 32 ustawy o Rzeczniku Rzecznik Finansowy obowiązany będzie zatem ustalić możliwości finansowe podmiotu rynku finansowego, co powinno nastąić w szczególności na podstawie analizy odpowiednich sprawozdań finansowych. Warto natomiast raz jeszcze zaznaczyć, że maksymalna wysokość kary pieniężnej, jaką Rzecznik może nałożyć na podstawie art. 32 ustawy o Rzeczniku, nie jest bardzo wysoka. Stąd, co do zasady, kara taka, w szczególności jeżeli nie będzie się mieścić w górnym pułapie limitu, nie powinna stanowić problemu dla podmiotu runku finansowego.

Artykuły 189e i 189f k.p.a. przewidują natomiast sytuacje, w których mimo naruszenia prawa kara nie zostanie nałożona. Jako że art. 32 (ust. 2) ustawy o Rzeczniku nie normuje tych kwestii, należy przyjąć, iż wskazane przepisy k.p.a. znajdą w tym zakresie zastosowanie. Po pierwsze, oznacza to, że w przypadku gdy do naruszenia prawa doszło wskutek działania siły wyższej, podmiot rynku finansowego nie 
będzie podlegać ukaraniu ${ }^{81}$. Po drugie, Rzecznik Finansowy w drodze decyzji obowiązany będzie odstąpić od nałożenia kary i poprzestać na pouczeniu takiego podmiotu, jeżeli waga naruszenia prawa jest znikoma, a strona zaprzestała naruszania prawa ${ }^{82}$. Nie budzi wątpliwości, że w omawianym przypadku odstąpienie nastąpi tylko wówczas, gdy obie przesłanki spełnione zostaną kumulatywnie. Po trzecie, obowiązek odstąpienia istnieje również wówczas, gdy na podmiot rynku finansowego za to samo zachowanie prawomocną decyzją została uprzednio nałożona administracyjna kara pieniężna przez inny uprawniony organ administracji publicznej i kara ta spełnia cele, dla których miałaby być nałożona administracyjna kara pieniężna przez Rzecznika Finansowego $^{83}$. Wydaje się, iż w omawianym zakresie zasadniczo w grę mogą wchodzić kary nakładane przez KNF lub Prezesa UOKiK.

W tym kontekście warto wskazać, że z dniem 10 stycznia 2017 r. na mocy art. 55 ustawy o pozasądowym rozwiązywaniu sporów ${ }^{84}$ znowelizowany został art. 5 ust. 3 pkt 3 ustawy o przeciwdziałaniu nieuczciwym praktykom rynkowym ${ }^{85}$. Zgodnie z obecnym brzmieniem tego przepisu wprowadzające w błąd działanie (które w konsekwencji może oznaczać nieuczciwą praktykę rynkową ${ }^{86}$ ) może w szczególności dotyczyć obowiązków przedsiębiorcy związanych z produktem, w tym usług serwisowych i procedury reklamacyjnej, dostawy, niezbędnych usług, części, wymiany lub naprawy. Natomiast zgodnie z art. 6 ust. 1 u.p.n.p.r. praktykę rynkową uznaje się za zaniechanie wprowadzające w błąd (a w konsekwencji jako nieuczciwą praktykę rynkową ${ }^{87}$ ), jeżeli pomija istotne informacje potrzebne przeciętnemu konsumentowi do podjęcia decyzji dotyczącej umowy i tym samym powoduje lub może powodować podjęcie przez przeciętnego konsumenta decyzji dotyczącej umowy, której inaczej by nie podjął. Artykuł 6 ust. 4 pkt 4 u.p.n.p.r. precyzuje natomiast, że w przypadku propozycji nabycia produktu za istotne informacje uznaje się w szczególności uzgodnienia dotyczące sposobu płatności, dostawy lub wykonania produktu oraz procedury

\footnotetext{
${ }^{81}$ Artykuł 189e k.p.a.

${ }^{82}$ Artykuł $189 \mathrm{f} \S 1$ pkt 1 k.p.a.

${ }^{83}$ Artykuł $189 f \S 1$ pkt 2 k.p.a.

${ }^{84}$ Ustawa z dnia 23 września 2016 r. o pozasądowym rozwiązywaniu sporów konsumenckich (Dz.U. 2016, poz. 1823).

${ }^{85}$ Ustawa z dnia 23 VIII 2007 r. o przeciwdziałaniu nieuczciwym praktykom rynkowym (tekst jedn. Dz.U. 2017, poz. 2070), dalej „u.p.n.p.r.".

${ }^{86}$ Artykuł 4 ust. 1 i 2 w zw. $z$ art. 5 ust. $1-4$ u.p.n.p.r.

${ }^{87}$ Artykuł 4 ust. 1 i 2 w zw. $z$ art. 6 ust. $1-5$ u.p.n.p.r.
} 
rozpatrywania reklamacji. Tym samym działanie lub zaniechanie podmiotów rynku finansowego powodujące naruszenie niektórych przepisów ustawy o Rzeczniku w odniesieniu do konsumentów może się wiązać nie tylko z karą pieniężną nakładaną przez Rzecznika Finansowego na podstawie art. 32 tego aktu, lecz może być również rozpatrywane jako nieuczciwa praktyka rynkowa w rozumieniu u.p.n.p.r., a w konsekwencji jako praktyka naruszająca zbiorowe interesy konsumentów (art. 24 ust. 2 pkt 3 ustawy u.o.k.i.k.). W przypadku wydania w tym zakresie decyzji przez Prezesa UOKiK, w konkretnych okolicznościach mogłoby to oznaczać konieczność zastosowania przez Rzecznika Finansowego art. $189 f \S 1$ pkt 2 k.p.a. Należy przy tym pamiętać, że u.p.n.p.r. określa zasady przeciwdziałania nieuczciwym praktykom rynkowym w interesie konsumentów i w interesie publicznym ${ }^{88}$, zaś ustawa u.o.k.i.k. wprowadza zakaz praktyk naruszających zbiorowe interesy konsumentów ${ }^{89}$, podczas gdy ustawa o Rzeczniku ma na celu ochronę klientów podmiotów rynku finansowego ${ }^{90}$ będących osobami fizycznymi, którzy nie muszą mieć jednak przymiotu konsumenta.

Artykuł 189f § 2 i 3 k.p.a. reguluje natomiast fakultatywne odstapienie od nałożenia kary pieniężnej. W przypadkach zatem, gdy nie zachodzą przesłanki do obligatoryjnego odstąpienia od nałożenia kary (art. 189f $\S 1$ k.p.a) i jeżeli pozwoli to na spełnienie celów, dla których miałaby być nałożona kara pieniężna, Rzecznik Finansowy, w drodze postanowienia, może wyznaczyć stronie termin do przedstawienia dowodów potwierdzających usunięcie naruszenia prawa ${ }^{91}$ lub powiadomienie właściwych podmiotów o stwierdzonym naruszeniu prawa, określając termin i sposób powiadomienia ${ }^{92}$. Jeżeli podmiot rynku finansowego przedstawi dowody potwierdzające wykonanie postanowienia, Rzecznik Finansowy odstępuje od nałożenia administracyjnej kary pieniężnej i poprzestaje na pouczeniu.

Nie powinno też budzić wątpliwości, że do Rzecznika Finansowego zastosowanie znajdzie art. 189g \& 1 i 3, który reguluje zasady przedawniania się administracyjnych kar pieniężnych ${ }^{93}$. Kara pieniężna nie

${ }^{88}$ Artykuł $1 \mathrm{w}$ zw. z art. 2 pkt 2 u.p.n.p.r.

${ }^{89}$ Artykuł 24 i n. (Dział IV) w zw. z art. 1 w zw. z art. 4 pkt 12 ustawy u.o.k.i.k.

${ }^{90}$ Artykuł 2 pkt 1 ustawy o Rzeczniku.

${ }^{91}$ Artykuł 189f $\S 2$ pkt 1 k.p.a.

${ }^{92}$ Artykuł 189f § 2 pkt 2 k.p.a.

${ }^{93} \mathrm{~W}$ związku z tym, że art. 32 ustawy o Rzeczniku nie reguluje tych kwestii, nie znajdzie zastosowania art. $189 \mathrm{~g} \S 2$ k.p.a. 
będzie mogła zatem zostać nałożona na podmiot rynku finansowego, jeżeli upłynęło pięć lat od dnia naruszenia prawa albo wystąpienia skutków naruszenia prawa ${ }^{94}$. Ponadto kara pieniężna nałożona przez Rzecznika Finansowego nie będzie podlegać egzekucji, jeżeli upłynęło pięć lat od dnia, w którym kara powinna być wykonana ${ }^{95}$. Do Rzecznika Finansowego znajdzie również zastosowanie art. 189h k.p.a., regulujący kwestie związane $\mathrm{z}$ biegiem terminu przedawnienia nałożenia kary pieniężnej. Ponadto zastosowanie znajdą art. 189i-189k k.p.a., regulujące problematykę zaległych kar pieniężnych i biegu terminu przedawnienia egzekucji takiej kary, jak również zasady udzielania ulg w wykonaniu kary pieniężnej nałożonej na podstawie art. 32 ustawy o Rzeczniku.

\section{Postępowanie w sprawie}

Kończąc, warto poczynić kilka uwag odnośnie do postępowania prowadzonego na podstawie art. 32 ustawy o Rzeczniku. Asumpt do podjęcia działań w tym zakresie powinno dać powzięcie podejrzenia o możliwości naruszenia przez podmiot rynku finansowego przepisów wskazanych w art. 32 ust. 1 ustawy o Rzeczniku. Najczęściej informacja $\mathrm{w}$ tym zakresie powzięta zostaje $\mathrm{w}$ związku $\mathrm{z}$ rozpatrywaniem wniosków klientów bądź to samodzielnie przez Rzecznika, bądź to w wyniku wskazania klienta. Rzecznik może powziąć informację w tym zakresie również z urzędu, np. badając wzorce na podstawie art. 30 ustawy o Rzeczniku lub otrzymując zawiadomienia od innych podmiotów czy organów. W pierwszej kolejności Rzecznik powinien poinformować podmiot rynku finansowego o dostrzeganych (podejrzewanych) nieprawidłowościach i zwrócić się o zajęcie stanowiska w sprawie. W razie konieczności Rzecznik Finansowy powinien zażądać zaprzestania naruszeń i monitorować działania podmiotu rynku finansowego w tym zakresie. W przypadku podejrzenia, że naruszenia mimo wcześniejszych zapytań, upomnień lub ostrzeżeń w dalszym ciągu mogą się powtarzać, bądź też skutki naruszeń nie zostały usunięte, zasadne może się okazać wszczęcie postępowania administracyjnego na podstawie art. 32 ustawy o Rzeczniku.

\footnotetext{
${ }^{94}$ Artykuł 189g § 1 k.p.a.

95 Artykuł 189g § 3 k.p.a.
} 
W doktrynie ${ }^{96} \mathrm{i}$ w orzecznictwie ${ }^{97}$ przyjmuje się, że art. 61 k.p.a. nie stanowi samodzielnej podstawy do ustalenia, czy w danym przypadku obowiązuje zasada skargowości czy zasada oficjalności, gdyż przesądzają o tym przepisy prawa materialnego. Natomiast w razie gdy norma prawa materialnego expressis verbis nie przesądza, czy sprawa podejmowana jest na wniosek czy z urzędu, przyjmuje się, że gdy przedmiotem jest przyznanie uprawnienia - postępowanie oparte jest na zasadzie skargowości, gdy zaś przedmiotem jest nałożenie obowiązku - postępowanie wszczynane jest $\mathrm{z}$ urzędu ${ }^{98}$. W związku z powyższym należy przyjać, że na podstawie art. 32 ustawy o Rzeczniku w zw. z art. 61 § 1 k.p.a. postępowanie wszczynane jest z urzędu ${ }^{99}$. Kara pieniężna - co oczywiste - oznacza bowiem nałożenie na podmiot rynku finansowego określonego obowiązku.

W tym kontekście warto jednak wspomnieć o art. 31 k.p.a., na podstawie którego organizacja społeczna może w sprawie dotyczącej innej osoby występować z żądaniem wszczęcia postępowania lub dopuszczenia jej do udziału w postępowaniu, jeżeli jest to uzasadnione celami statutowymi tej organizacji i gdy przemawia za tym interes społeczny ${ }^{100}$. Rzecznik Finansowy, uznając żądanie organizacji społecznej za uzasadnione, postanawia o wszczęciu postępowania z urzędu lub o dopuszczeniu organizacji do udziału w postępowaniu ${ }^{101}$. Natomiast na postanowienie o odmowie wszczęcia postępowania lub dopuszczenia do udziału w postępowaniu organizacji społecznej służy zażalenie ${ }^{102}$.

${ }^{96}$ R. Stankiewicz, Komentarz do art. 61, w: Kodeks postępowania administracyjnego. Komentarz, pod red. M. Wierzbowskiego, A. Wiktorowskiej, Warszawa 2018.

${ }^{97}$ Wyrok NSA z 3 III 2006 r., sygn. I OSK 991/05, Legalis nr 271465; wyrok NSA z 22 III 2006 r., sygn. II GSK 28/06, Legalis nr 241315; wyrok NSA z 25 X 2006 r., sygn. II OSK 1257/05, Legalis nr 232954.

${ }_{98}$ Zob. przypisy nr 96 i 97 w niniejszym tekście.

${ }^{99}$ Za datę wszczęcia postępowania z urzędu należy przyjąć pierwszą czynność urzędową wobec strony lub czynność podjętą w sprawie przez organ administracji publicznej z urzędu (wyrok NSA z 20 I 2010 r., sygn. II GSK 321/09, Legalis nr 224515). Pierwszą taką czynnością uruchamiającą bieg postępowania administracyjnego z urzędu może być wynik kontroli dokonanej przez osoby uprawnione do działania w imieniu organu (wyrok NSA z 5 IV 2006 r., sygn. II GSK 28/06, Legalis nr 241315).

${ }^{100}$ Artykuł $31 \S 1$ k.p.a.

101 Artykuł 31 \& 2 zd. 1 k.p.a.

102 Artykuł $31 \S 2$ zd. 2 k.p.a. Warto też pamiętać o treści art. 61a k.p.a., zgodnie z którym, gdy żądanie o wszczęcie postępowania administracyjnego zostało wniesione przez osobę niebędącą stroną lub z innych uzasadnionych przyczyn postępowanie nie może być wszczęte, organ administracji publicznej wydaje postanowienie o odmowie wszczęcia postępowania (na które przysługuje zażalenie). 
Postępowanie administracyjne prowadzone na podstawie art. 32 ustawy o Rzeczniku w zw. z art. 61 \& 1 k.p.a. powinno zmierzać do ustalenia wszystkich istotnych okoliczności faktycznych i prawnych związanych z podejrzeniem naruszenia przepisów ustawy o Rzeczniku, mogącego uzasadniać nałożenie kary ${ }^{103}$. Rzecznik Finansowy powinien poinformować podmiot rynku finansowego o wszczęciu postępowania (art. $61 \S 4$ k.p.a.), doręczając zawiadomienie zgodnie z art. 39 k.p.a. Dobrą praktyka, znajdującą oparcie w art. $10 \S 1$ k.p.a., jest też wskazywanie w takim zawiadomieniu o możliwości wypowiedzenia się przez stronę postępowania i w związku z tym wyznaczanie jej stosownego terminu ${ }^{104}$. W zawiadomieniu może się również znaleźć wniosek o przekazanie informacji lub dokumentów, które mogą mieć istotne znaczenie dla rozstrzygnięcia sprawy.

Biorąc pod uwagę, że postępowanie prowadzone na podstawie art. 32 ustawy o Rzeczniku może się zakończyć nałożeniem na podmiot rynku finansowego kary pieniężnej, dobrym obyczajem byłoby również, aby w przypadku, w którym w wyniku prowadzonego postępowania Rzecznik Finansowy istotnie zmierzać będzie do nałożenia kary, wcześniej skierował do podmiotu rynku finansowego zawiadomienie, zawierające wyczerpujące informacje dotyczące stawianych zarzutów. Przedstawianie takiego zawiadomienia powinno nastąpić, gdy Rzecznik Finansowy uzna, że zakończył etap gromadzenia materiału dowodowego. Można się w tym zakresie - na zasadzie ostrożnej analogii - odwołać do tzw. „Statement of Objections" stosowanego przez Komisję Europejska, który ma na celu podwyższenie standardów sprawiedliwości proceduralnej, w tym

${ }^{103}$ Artykuł 7, art. 77, art. 80, art. $107 \S 1$ pkt 6 i § 3 k.p.a.

${ }^{104}$ Wyrok NSA z 15 II 2017 r., sygn. II OSK 1385/16, Legalis nr 1605267. Równocześnie NSA stwierdził: „Nie sposób uznać terminu wyznaczonego stronom postępowania na zajęcie stanowiska w zawiadomieniu o wszczęciu postępowania za termin przewidziany przez przepis prawa albo za opóźnienie w załatwieniu sprawy niezależne od organu administracji lub zawinione przez strony postępowania. Nie jest to jednakże termin przewidziany przepisami prawa. Ponadto w związku z tym, że związany jest on ze zwykłymi obowiązkami organu administracji, wynikającymi z art. 10 § 1 i art. $61 \S 4$ KPA, nie można uznać go za zdarzenie nadzwyczajnie i niezależne od organu administracji lub zawinione przez strony". Takie stanowisko może jednak budzić wątpliwości. Oznacza bowiem, że terminy te należy wliczać do okresu trwania postępowania (art. 35 $\S 5$ k.p.a.). Jeżeli zatem organ wyznaczy stronie np. tygodniowy termin na wypowiedzenie się w przedmiocie zawiadomienia, jak również tygodniowy termin na końcowe zapoznanie się z aktami sprawy i składanie wniosków (art. 10 k.p.a.), to zakończenie sprawy w terminach określonych w art. 35 § 3 k.p.a. może się okazać niezwykle utrudnione lub niemożliwe. 
prawa przedsiębiorcy do obrony ${ }^{105}$. Uprawnienie (a być może nawet obowiązek) Rzecznika Finansowego w tym zakresie można wywieść z art. 9 k.p.a., zgodnie z którym organy administracji publicznej są obowiązane do należytego i wyczerpującego informowania stron o okolicznościach faktycznych i prawnych, które mogą mieć wpływ na ustalenie ich praw i obowiązków będących przedmiotem postępowania administracyjnego. Warto wskazać, że od 1 września 2015 r. Prezes UOKiK w sprawach praktyk ograniczających konkurencję, praktyk naruszających zbiorowe interesy konsumentów oraz nakładania kar pieniężnych za naruszenie przepisów ustawy u.o.k.i.k. przedstawia stronom „Szczegółowe uzasadnienie zarzutów" ${ }^{\prime 106}$, stanowiące odpowiednik "Statement of Objections" stosowanego przez Komisję Europejską. Dokument taki zawiera szczegółowe uzasadnienie faktyczne i prawne stawianych zarzutów oraz wszystkie istotne fakty oraz dowody, na podstawie których zamierza oprzeć decyzję ${ }^{107}$. Ponadto przedstawia ocenę prawną ustalonych faktów, tak aby strona postępowania miała możliwość ustosunkowania się do niej ${ }^{108}$. Ma on charakter przygotowawczy i stanowi czynność materialno-techniczną poprzedzającą wydanie decyzji administracyjnej ${ }^{109}$. Pożądane byłoby analogiczne postępowanie przez Rzecznika Finansowego, choć należy pamiętać, że ustawa u.o.k.i.k. przewiduje dla postępowań prowadzonych przez Prezesa UOKiK dłużnie niż k.p.a. terminy ${ }^{110}$.

Oczywiście, niezależnie od powyższego, na Rzeczniku Finansowym ciążyć będzie - wynikający z art. 10 § 1 k.p.a. - obowiązek zapewnienia podmiotowi rynku finansowego czynnego udziału w każdym stadium postępowania. W związku z tym przed wydaniem decyzji Rzecznik powinien umożliwić podmiotowi rynku finansowego wypowiedzenie się co do zebranych dowodów i materiałów oraz zgłoszonych żądań. W świetle ugruntowanego orzecznictwa sądów administracyjnych 2018).

$105 \mathrm{http}: / /$ ec.europa.eu/competition/antitrust/procedures_101_en.html (dostęp: $5 \mathrm{~V}$

${ }^{106}$ Wyjaśnienia dotyczace przedstawiania szczegółowego uzasadniania zarzutów w sprawach: 1) praktyk ograniczających konkurencje, 2) praktyk naruszajacych zbiorowe interesy konsumentów oraz 3) nakładania kar pieniężnych za naruszenie przepisów ustawy, Warszawa, 1 IX 2015 r., https://uokik.gov.pl/aktualnosci.php?news_id=11816 (dostęp: 5 V 2018), https://uokik.gov.pl/aktualnosci.php?news_id=11875 (dostęp: 10 VII 2018).

${ }^{107}$ Ibidem.

${ }^{108}$ Ibidem.

${ }^{109}$ Ibidem.

${ }^{110}$ Art. 92, 96, 96a, 99e oraz 104 ustawy u.o.k.i.k. Zob. też przypis nr $104 \mathrm{w}$ niniejszym tekście. 
oznacza to obowiązek zawiadomienia podmiotu rynku finansowego o zebraniu materiału dowodowego, o możliwości zapoznania się z nim oraz o prawie do składania wniosków ${ }^{111}$.

\section{Podsumowanie}

Możliwość nakładania przez Rzecznika Finansowego kar pieniężnych na podmioty rynku finansowego za uchybienia przepisom ustawy o Rzeczniku stanowi novum w polskim prawie, stąd w praktyce mogą się pojawić wątpliwości związane ze stosowaniem nowych przepisów. Niemniej, w związku z tym, że kara pieniężna nakładana jest - jak należy przyjąć na podstawie decyzji administracyjnej, należy się w tym zakresie wspierać wskazówkami interpretacyjnymi wypracowanymi w orzecznictwie sądów administracyjnych na tle kar pieniężnych nakładanych przez inne

${ }^{111}$ W wyroku NSA z 14 VI 2016 r., sygn. II OSK 2473/14, Legalis nr 1509641, sąd ten stwierdził, że "Obowiązki organu administracji wynikające z zasady czynnego udziału obejmują wszystkie fazy postępowania. Obejmują także obowiązek umożliwienia wypowiedzenia się co do zebranego materiału dowodowego, który to obowiązek dotyczy tylko etapu po zakończeniu postępowania wyjaśniającego, a jeszcze przed wydaniem decyzji, z tym że strona ma uprawnienia do wypowiedzenia się także w toku postępowania wyjaśniającego. Obowiązek zapewnienia stronom czynnego udziału w postępowaniu obejmuje fazę wszczęcia postępowania, fazę postępowania wyjaśniającego, fazę między zakończeniem postępowania wyjaśniającego a wydaniem decyzji oraz fazę wydawania decyzji".

W wyroku WSA w Lublinie z 24 I 2017 r., sygn. III SA/Lu 1081/16, Legalis nr 1722261, sąd wskazał, że "Zgodnie z art. $10 \S 1$ k.p.a. organy administracji publicznej obowiązane są zapewnić stronom czynny udział w każdym stadium postępowania, a przed wydaniem decyzji umożliwić im wypowiedzenie się co do zebranych dowodów i materiałów oraz zgłoszonych żądań. Wyrażona w przywołanym przepisie zasada czynnego udziału strony w postępowaniu obliguje organ prowadzący postępowanie do stworzenia stronie prawnych możliwości podejmowania czynności procesowych w obronie swoich interesów".

Warto też pamiętać, że zarzut naruszenia art. $10 \S 1$ k.p.a. przez niezawiadomienie strony o zebranym materiale dowodowym i możliwości składania wniosków może jednak odnieść skutek wówczas, gdy stawiająca go strona wykaże, iż zarzucane naruszenie uniemożliwiało jej dokonanie konkretnych czynności procesowych (zob. wyrok NSA z 9 IV 2014 r., sygn. I OSK 2572/12, Legalis nr 1161472; wyrok NSA z 21 II 2018 r., sygn. II OSK 1125/17, Legalis nr 1759206). Podobnie wyrok NSA z 4 VII 2017 r., sygn. II OSK 546/16, Legalis nr 1649360, w którym sąd stwierdził, że „Nawet jeśli doszłoby do naruszenia wskazanego art. $10 \S 1$ k.p.a., to podstawa kasacyjna obejmująca zarzut naruszenia tego przepisu ( $\mathrm{w}$ powiązaniu z odpowiednimi przepisami procedury sądowoadministracyjnej) może być skuteczna (tj. prowadzić do uwzględnienia skargi kasacyjnej) jedynie w przypadku, gdy zarzucane uchybienie mogło mieć istotny wpływ na wynik sprawy. Przy czym wykazanie, że taki potencjalny istotny wpływ na rozstrzygnięcie zachodzi, należy do strony". 
organy, w tym zwłaszcza przez KNF. Biorąc pod uwagę, że możliwość nałożenia przez Rzecznika kary mieści się w granicach tzw. uznania administracyjnego, ingerencja w sferę praw i obowiązków podmiotu rynku finansowego powinna mieć głębokie uzasadnienie merytoryczne i zmierzać do realizacji ustawowych zadań Rzecznika Finansowego. Należy bowiem pamiętać, że w świetle orzecznictwa sądów administracyjnych z decyzjami uznaniowymi wiąże się zwiększona kontrola sądów administracyjnych, wykonywana z punktu widzenia ich legalności. Dlatego w pierwszej kolejności Rzecznik powinien podejmować miękkie działania o charakterze upominawczym, ostrzegawczym lub prewencyjnym. Niemniej, w konkretnych okolicznościach, nałożenie kary pieniężnej może być uzasadnione nawet w przypadku jednostkowych naruszeń przepisów wskazanych w art. 32 ust. 1 ustawy o Rzeczniku. Jeśli zaś chodzi o wysokość kary, należy zapewnić jej zgodność $\mathrm{z}$ zasadą proporcjonalności. W tym zakresie konieczne będzie łączne stosowanie art. 32 ust. 2 ustawy o Rzeczniku w związku z odpowiednimi przepisami Działu IVa k.p.a., regulującymi sprawy nakładania lub wymierzania administracyjnych kar pieniężnych i udzielania ulg w ich wykonaniu. W obecnym stanie prawnym Rzecznik Finansowy może nałożyć karę pieniężną wyłącznie na podmiot rynku finansowego, mimo że ustawa o Rzeczniku przewiduje również uprawnienie do podejmowania odpowiednich działań i czynności wobec innych podmiotów. De lege ferenda warto rozważyć poszerzenie kompetencji Rzecznika w tym zakresie. Warto także zapewnić większą jasność i spójność przepisów ustawy o Rzeczniku, tak aby nie budziło wątpliwości, naruszenie jakich obowiązków może skutkować nałożeniem kary pieniężnej. Ponadto warto rozważyć wprowadzenie takich mechanizmów sankcyjnych, które pozwolą na skuteczne egzekwowanie wykonywania przez podmioty rynku finansowego obowiązków wynikających z ustawy o Rzeczniku. Możliwość nałożenia przez Rzecznika Finansowego kary pieniężnej (a nawet jej nałożenie) nie zawsze pozwala na zrealizowanie tego celu.

\section{COMPETENCE OF THE FINANCIAL OMBUDSMAN TO IMPOSE FINES ON FINANCIAL MARKET ENTITIES}

\section{Su m mary}

The subject of this article is the competence of the Financial Ombudsman to impose financial penalties on financial market entities for violations of the provisions of 
the Act of 5 August 2015 on complaints handling procedures by financial market entities and on the financial Ombudsman. One of the main tasks of the Financial Ombudsman is to enforce the proper performance by financial market entities of their obligations under the Act. For this purpose, Article 32(1) thereof provides that in the event of a breach of the provisions set out in the Act the Financial Ombudsman may, by way of a decision, impose a fine of up to PLN 100 000. The short duration of the new provisions and, consequently, the lack of case law outlining the directions of their interpretation may, particularly in the initial period, give rise to doubts as to their application. The aim of the article is to analyse possible disputable issues and provide proposals for their resolution. In particular, it is necessary to discuss the conditions for imposing a fine on a financial market entity. In this regard it is important to analyse both - the specific torts indicated in Article 32(1) of the said Act, as well as the general rules upon which the imposition of administrative fines by the Financial Ombudsman is possible. Also important is the consideration of the rules for determining the amount of the fine and in this matter the mutual relationship between Article 32 and the provisions of section IVa of the Act of 14 June 1960. Finally, amendments to certain provisions of the exiting laws are being proposed in order to increase the effectiveness of actions undertaken by the Financial Ombudsman and consequently to increase the level of protection of clients of financial market entities.

Keywords: administrative fine - administrative decision - Financial Ombudsman financial market entity 